\title{
insígnia, escafandro, sátira e locus: análise de processos criativos em comprovisação ${ }^{1}$
}

insignia, escafandro, sátira and locus: analysis of a creative processes in comprovisation

Arthur Faraco ${ }^{2}$ Universidade de São Paulo - USP arthurfarac067@gmail.com ORCID: 0000-0002-0641-9625 


\section{Resumo}

Nosso objeto de análise neste artigo é o conjunto de peças insígnia, escafandro, sátira e locus, criadas pelo autor. Estas são consideradas como experimentos em comprovisação, devido às características de seus processos criativos. Comprovisação, como um termo recente na literatura, não há até o momento um consenso; por isto, reunimos aqui possíveis antecedentes, as noções sobre e práticas que buscam na comprovisação sua caracterização. Distinguimos duas vertentes teóricas sobre o assunto, e realizamos considerações próprias almejando uma compreensão do termo a partir de uma interligação dos fluxos de interpretação e improvisação - estes vinculados a noções de processos generativos da performance e da compreensão de Falleiros (2012) sobre o pacto. Por meio de ferramentas tradicionais de análise, e da perspectiva notacional de Bhagwati (2013), acreditamos que a ressignificação dos gestos improvisados existentes nas peças analisadas aponta para a compreensão destas como experimentos em comprovisação.

Palavras-chave: Comprovisação. Composição. Improvisação. Processos Criativos. Performance.

\section{Abstract}

Our objects of analysis in this article are the musical pieces named insignia, escafandro, sátira and locus, created by the author. These are considered to be experiments in comprovisation, given the characteristics of their creative processes. Comprovisation, as a recent term in the literature, has no consensus so far; therefore, we gather here possible antecedents, the notions about and practices that seek in comprovisation its characterization. We distinguish two theoretical strains on the subject, and we carry out our own considerations aiming at an understanding of the term from an interconnection of the flows of interpretation and improvisation - these linked to notions of generative processes of performance and the understanding of Falleiros (2012) on the pact. Through traditional tools of analysis, and the notational perspective of Bhagwati (2013), we believe that the resignification of improvised gestures in the analyzed pieces points to the understanding of these as experiments in comprovisation.

Keywords: Comprovisation. Composition. Improvisation. Creative Process. Performance.

\footnotetext{
1 Este artigo refere-se a resultados obtidos ao longo da pesquisa de mestrado do autor, realizado na Unicamp sob orientação do Prof. Dr. Manuel Falleiros, a quem agradeço pelas contribuições realizadas.

2 Doutorando em Música pela Universidade de São Paulo (USP), mestre em música pela Unicamp e graduado em Música pela Universidade Estadual de Londrina (UEL). Atualmente atua como professor colaborador no Departamento de Artes no curso de Graduação em Música na Universidade Estadual de Ponta Grossa (UEPG). Possui trabalho de pesquisa vinculado à livre improvisação coletiva e à cognição musical.
} 


\section{Comprovisação: antecedentes, noções e práticas}

A fim de contextualizarmos o panorama teórico-prático sobre o qual as peças insígnia, escafandro, sátira e locus foram criadas, abordaremos noções sobre a prática musical contemporânea denominada comprovisação, e se podemos distinguir qualidades representativas desta que a diferenciam da pluralidade de processos criativos musicais atuais. Percebemos que o surgimento do termo está vinculado aos diversos debates sobre a relação entre composição e improvisação, sendo eles intensificados especialmente em práticas posteriores às denominadas vanguardas artísticas.

Esta relação entre os processos criativos da improvisação e da composição é, por vezes, tomada como opositora, binária, devido a dois fatores: a própria natureza dos processos e uma supressão histórica da improvisação em vista de uma hegemonia da composição ao longo dos séculos XVIII e XIX (MOORE, 1992; LEWIS, 1996). Em uma extensa revisão bibliográfica sobre as visões de artistas e pesquisadores a respeito da relação composição - improvisação, Stenström (2009) demonstra alguns pontos principais envolvidos na diferenciação entre os processos: a composição é construída em tempo diferido (e, desta maneira, passível de correções), o que gera uma individualização no processo (dado que há a figura do compositor); é documentada por meio da notação musical, em conseguinte, há possibilidade de reprodução da peça em ambientes diferentes com músicos diversos, visto que a composição seria, nesta percepção, um produto (mesmo que sua execução ocorra a partir da performance); a improvisação é realizada em tempo real (ações musicais sendo pensadas e criadas no momento da performance); normalmente não possui documentação (não é notada musicalmente antes da sua execução); há uma valorização do aspecto processual, muitas vezes com foco em uma expressão coletiva ao invés de individual (STENSTRÖM, 2009, p. 165 - 170; BAILEY, 1993). Entre outras diversas caracterizações de composição e improvisação, acreditamos que estas sintetizam uma percepção de binariedade entre os processos.

Tais visões são, em nossa percepção, defasadas, tendo em vista a pluralidade de práticas composicionais e improvisatórias existentes não somente na cultura de tradição eurocêntrica, mas em culturas que, às vezes, não distinguem composição e improvisação ou não possuem termos adequados a tais processos, como apontam pesquisas etnomusicológicas como a de Nettl e Russel (1998). Cabe mencionar que o próprio discurso da supressão histórica da improvisação ao longo dos séculos XVIII e XIX já é questionado, dado que a hegemonia aparente da composição se dá pela documentação histórica realizada da música da época. A figura do improvisador, ou a prática de improvisação em si não é apagada ou deixa de existir (FURLANETE, 2019).

Além dos pontos supramencionados, percebe-se que não somente nas práticas musicais do século XX a improvisação "reapareceria" como parte integrante tanto dos processos criativos quanto da própria formação musical. Ao longo do denominado "período comum" (COSTA, 2001), no qual ocorreria a mencionada supressão histórica da improvisação, esta, como prática musical, era parte integrante da vida cotidiana do músico, sendo característica de sua formação. Nomes reconhecidos da composição musical ao longo deste período eram, também, improvisadores. Há mesmo elementos 
composicionais em peças deste período que demonstram a valorização da improvisação: como exemplo tradicional, no período barroco há a presença do baixo contínuo improvisado (ou, como Bailey [1994] menciona, extemporizado); as cadências em concertos para instrumentistas ao longo dos períodos clássico e romântico simbolizam um momento de demonstração (por vezes, virtuosísticas) da capacidade improvisatória do músico. Portanto, cabe compreendermos aqui que a relação entre composição e improvisação não é tomada como opositora, mas sim complementar, integradora. Pode-se dizer que esta relação de oposição tem força a partir de debates teóricos ocorrentes especialmente ao longo da segunda metade do século XX, como por exemplo, as compreensões de George Lewis (1996) e Anthony Braxton sobre a relação improvisação e indeterminação3 ${ }^{3}$ ou a visão de Michael Nyman (1999) sobre música experimental e música moderna. Desta forma, buscaremos relacionar comprovisação a partir destes debates teóricos, mas com vista à integração e complementaridade realmente existente entre os processos criativos composicionais e improvisatórios existentes na história da música.

Percebemos que um possível surgimento da compreensão sobre comprovisação tem base em três grandes "correntes": a estética da indeterminação (CANONNE, 2016), na qual englobamos os processos criativos da tradição de música de concerto europeia que surgem após 1950, os diversos movimentos estilísticos do jazz estadunidense e a improvisação livre. Acreditamos que estas práticas abordam a "zona cinza" entre a composição e a improvisação, ou seja, o que seriam os entremeios da abordagem opositora entre os processos de criação. Ainda: abordam os entremeios de um "contínuo" no qual existiriam opostos (em sua vez, ideais) da composição totalmente notada e da improvisação livre (NETTL; RUSSEL, 1998; BHAGWATI, 2013; CANONNE, 2018a).

A estética da indeterminação, nomeação cunhada por Canonne (2016), engloba as práticas derivadas de uma tradição da música de concerto europeia que se vale de ferramentas composicionais com vista à geração de aberturas, a fim de que o intérprete possua uma função de atualizador da peça musical (KUEHN, 2012). Em um contexto pós-Segunda Guerra Mundial, compositores buscam retomar experimentalismos de práticas do início do século XX (que abrangem as vanguardas artísticas) - práticas estas como o abandono do sistema tonal como norteador da estrutura composicional, o uso do timbre como elemento similar a aspectos como altura e rítmica, a inserção do ruído e sons outrora não considerados como musicais nas peças, experimentações com novas formas musicais, o início da música eletrônica ou com suportes eletrônicos, entre outras (SIMMS, 1995; LEEW; GROOT, 2005).

O jazz estadunidense possui uma gama estilística que perpassa o século XX e, a partir da década de 1940, quando se inicia o que é conhecido como bebop, a improvisação se torna cerne da prática jazzística. O bebop é por vezes considerado como a mú-

3 Lewis (1996) levanta este debate, idealizando o que considera como duas tradições de improvisação: a eurológica (vinculada à estética da indeterminação) e a afrológica (vinculada especialmente ao jazz estadunidense). Na visão do autor, há na tradição eurológica uma negação ou supressão do termo improvisação por parte dos compositores, devido à compreensão por parte destes de que a improvisação gera automatismos na peça, descaracterizando- $a$, e ao intérprete é somente delegada a função de atualizador, não sendo este uma parte constituinte do processo criativo - uma manutenção da figura tradicional e eurocêntrica do compositor. 
sica experimental afro-americana (LEWIS, 1996), ou como afro-modernismo (STEWART, 2011), dado que, segundo os autores que analisam a prática, seria um movimento com princípios semelhantes aos experimentalismos ocorrentes na estética da indeterminação, como já mencionado. No bebop, instaurou-se um "modelo" recorrente de performance: há uma estrutura, delimitada por um quadro harmônico que se repete, além de uma melodia principal, normalmente executada uma vez previamente às improvisações. Estas ocorrem em acordo com o quadro harmônico - tal modelo é denominado chorus. Além deste modelo, há um respeito por elementos idiomáticos, melódicos e rítmicos, característicos da performance no jazz. Em meados da década de 1950, músicos iniciam um afastamento destes preceitos - o abandono da forma chorus principalmente - dando início a uma prática denominada free jazz. Nesta prática, as improvisações não ocorrem mais sobre uma sequência harmônica predeterminada, mas são realizadas a fim de gerar esta harmonia em tempo real. Cria-se um aspecto interativo que se diferencia do bebop: neste, enquanto a interação é compreendida a partir da relação entre solista e acompanhadores, no free jazz há uma ampliação da visão do coletivo, porém não abandona os elementos idiomáticos como estilos de condução ou de contorno melódico (JOST, 1994).

A improvisação livre é fruto de um encontro destas tradições até aqui relatadas; ou seja, da estética da indeterminação e dos preceitos do free jazz (CANONNE, 2016). A prática em seus primórdios têm como base um abandono dos elementos predeterminados e idiomáticos que constituíam as poéticas das práticas artísticas contemporâneas. Desta forma, no início das práticas que atualmente são nomeadas como improvisação livre, músicos buscavam maneiras de desvinculação de elementos predeterminados para a criação musical, sejam eles a notação musical ou os idiomatismos estilísticos. A "liberdade" em que esta prática se engendra consiste nesta busca de uma forma radical de separação entre as "limitações" que seriam impostas pelos sistemas composicionais/ improvisatórios (FALLEIROS, 2013; 2018). Ao longo dos anos, a prática vem se consolidando como objeto artístico, de estudo acadêmico e, por vezes, como ferramenta didática. Diversas considerações são realizadas sobre a visão da prática atualmente. Como exemplo, Falleiros (2013) a considera como hiperimprovisação, dado o contexto social vigente, além de uma visão por vezes romantizada das quebras radicais do início da prática que considera como herança distorcida. Outras nomenclaturas são dadas à prática, buscando caracterizá-la de maneira que percebemos como uma fuga de tal herança: um exemplo contundente é o curso de Alain Sauvoret (de 1992 a 2007 no Conservatório de Paris), o qual denomina como improvisação generativa (SAUVORET, 2010).

Uma performance de LIC tem como base primária a não existência de um referente predeterminado. De acordo com Pressing (1988; 1998), o referente é uma predeterminação estrutural que auxilia o improvisador em sua criação. Como a LIC não possui um referente, a criação é espontânea de acordo com as proposições sonoras dos músicos em tempo real (CANONNE; GARNIER, 2011; 2015a; 2015b). À vista disto, uma possível coesão musical surge a partir da interação entre os músicos - tal interação tem como um de seus objetivos a criação de uma forma percebida, além de um resultado satisfatório para os músicos envolvidos (CANONNE; GARNIER, 2015a). Com isto, Costa 
e Schaub (2013) buscam ampliar a noção de referente para a LIC: este seria partilhado e temporário, criado em tempo real. Algumas visões fundamentam tal noção, como os trabalhos de Canonne e Garnier (2015a), visto que este referente partilhado pode ser considerado como um elemento emergente de um sistema complexo, o qual a LIC é um demonstrativo (FARACO, 2020; SAWYER, 2003; BORGO, 2005, 2006; HAENISCH, 2011; CANONNE; GARNIER, 2015a).

Dado isto, em uma performance de livre improvisação, os músicos agem de maneira coletiva a fim de uma criação em tempo real baseada somente nas ações que ocorrem no momento, constituindo uma forma; consequentemente, há o abandono de uma estrutura preestabelecida. Ressaltamos a interatividade como uma das principais características, sendo que é por meio dela que os músicos realizam seus gestos. Dada esta característica, a prática é por vezes considerada como um "jogo", visto que ocorrem negociações ao longo da performance que podem se caracterizar como um lance, e este pode ser acatado ou não por outros participantes (COSTA, 2016; FALLEIROS, 2012). Estes elementos característicos da improvisação livre e um crescente interesse pela prática por compositores e improvisadores ao longo do tempo dão base para o surgimento de expressões que buscam adaptar os predicados da improvisação livre (BRESSON; CHADABE, 2017). A comprovisação seria, portanto, uma destas expressões.

Atestamos os primeiros usos do termo comprovisação como inseridos no contexto relatado até o momento. O trombonista Paul Rutherfod utiliza o termo para descrever suas práticas com o grupo Iskra 1903 ao longo da década de 1970, em conjunto ao guitarrista Derek Bailey e o contrabaixista Barry Guy. Neste grupo, Rutherford menciona que seu processo criativo possui um caráter composicional, com a escrita de peças, porém era garantida aos músicos uma liberdade de improvisarem, recriarem ou mesmo substituírem as partes escritas (ALLEN, 2006; PAPAGEORGIOU, 2015, p. 64). Outra menção ao termo comprovisação está no álbum Dust to Dust, de 1991, de Butch Morris, em uma peça denominada The Bartok Comprovisation. O uso do termo, segundo Papageorgiou (2015, p. 94), pode ter relação com o sistema de improvisação dirigida criada por Butch Morris (denominado Conduction). Além disto, autores como Josef Cseres (apud FUJÁK, 2011) utilizam o termo ainda no século XX como "[...] expressão estilística ao descrever as poéticas de diferentes obras da música experimental contemporânea" (FUJÁK, 2011, p. 24 - tradução nossa).

Etimologicamente, comprovisação seria um neologismo caracterizador de práticas musicais que buscam utilizar processos da composição e da improvisação. Porém, atualmente, autores buscam compreender se o termo explicita uma prática que se destaca na música atual. Com isto, dividimos duas vertentes sobre noções de comprovisação, a partir das intersecções das visões dos autores que utilizam o termo. São estas: Comprovisação como prática emergente via o uso de tecnologias de áudio e Comprovisação como descrição abrangente de práticas musicais abertas.

Os autores que reunimos como representantes da primeira vertente partilham uma visão sobre comprovisação como prática musical contemporânea que envolve uma performance interativa, vinculando improvisações ou interpretações por parte do músico em conjunto a um sistema computacional (interface) construído, visando a intera- 
tividade. O aspecto composicional (e às vezes, estrutural) da peça reside na construção da interface; já o aspecto improvisatório residiria nas possibilidades dadas ao intérprete para interagir com o sistema. Segundo Joshua Mailman (2013, p. 357), a existência da comprovisação seria impossível sem o surgimento de novas tecnologias que pudessem mediar a interatividade - salientando que compreendemos estas novas tecnologias como programas de gravação e edição e softwares de processamento de áudio digital -, buscando desta maneira uma definição estrita sobre a prática. Em sua compreensão, a comprovisação seria composicional dado que "envolve a composição de algoritmos de geração de música guiados por uma preocupação estética [...]" (MAILMAN, 2013, p. 357, tradução nossa), e "o algoritmo semiestocástico pode ser considerado como 'improvisação', já que a determinação de certos detalhes não pode ser prevista com antecedência" (MAILMAN, 2013, p. 358, tradução nossa).

Cabe frisar que o autor parte de seu próprio processo criativo a fim de obter tal conclusão - processo este que utiliza coreografias e movimentos físicos do intérprete para que ocorra a interação em conjunto ao sistema computacional criado. Portanto, esta visão, apesar de buscar uma noção universalizadora de comprovisação, restringe-se ao próprio processo criativo individual. Richard Dudas (2010), semelhantemente, parte de seu processo criativo para explicar sua abordagem sobre a prática. $\mathrm{O}$ autor analisa as possibilidades de interação existentes em peças mistas, que possuem um instrumento acústico em interação com a eletrônica (seja o processamento de áudio ou tapes). Neste contexto, percebe-se dois possíveis tipos de relação entre composição e improvisação: "1) compor um 'instrumento' que pode ser improvisado ao longo da performance e, 2) improvisar com ferramentas a fim de criar materiais pré-composicionais" (DUDAS, 2010, p. 29, tradução nossa). Esta compreensão possui uma de suas bases na visão do compositor como um manipulador sonoro, análogo ao improvisador, previamente à disposição do material em uma estrutura. Trevor Wishart denomina este ato do compositor como improvisação lenta (VASSILANDONAKIS, 2009). Para Dudas (2010), o compositor de estúdio manipula as ferramentas tecnológicas à sua disposição em uma maneira improvisada e, por vezes, sem obter uma compreensão plena do produto. $O$ que considera como a construção de um instrumento musical eletrônico, supracitado, está relacionado à tal manipulação e imprevisibilidade da programação de, por exemplo, patches para o processamento sonoro real de instrumentos acústicos.

Esta compreensão da comprovisação a partir de uma relação entre intérprete/improvisador e interfaces possui respaldo em diversas práticas já documentadas. Como exemplo, Louzeiros (2017) cria o Comprovisador, um sistema computacional designado a gerar uma notação dinâmica a partir de uma improvisação realizada por músicos ao longo de uma performance. $O$ aspecto improvisatório consiste na produção de material primário por parte dos músicos; o aspecto composicional situa-se na resposta gerada pelo sistema computacional que é transmitida aos músicos por meio de uma notação (de viés tradicional). ${ }^{4}$ Os músicos, ao se depararem com tal notação, devem executá-la (LOUZEIROS, 2017). Outro sistema com finalidades similares é o Bucket System, pro-

4 Consideramos como a notação simbólica (BHAGWATI, 2013): notas inseridas em uma pauta de cinco linhas com altura, rítmica, dinâmica, articulação e expressão definidas. 
jetado por Dahlstedt et al. (2015). Este sistema possui como objetivo principal mapear possibilidades de interação - não tem como foco o resultado sonoro. Desta maneira, há a geração de uma forma a partir da emissão de "vontades" dos improvisadores por meio do programa - qual dinâmica, qual instrumentação no momento, caráter melódico/rítmico -; este as sorteia, e os improvisadores tocam a partir das indicações dadas. Ainda, outro sistema que se apoia nesta compreensão de comprovisação é denominado John, the semi-conductor, idealizado por Goudard (2018). É similar ao Bucket System (os músicos determinam aspectos da forma, não o resultado sonoro), porém a exibição aos músicos das respostas aleatórias geradas pelo computador se dá por meio de screen score - uma notação gráfica única que todos os participantes seguem (GOUDARD, 2018, p. 46). ${ }^{5}$

Autores como Hannan (2006) e Coleman (2016) caracterizam seus trabalhos artísticos como comprovisação, a partir da compreensão de edição de áudio de improvisações livres, gerando um produto composicional posteriormente. O primeiro, ao descrever seu processo criativo, cita a produção de um acervo sonoro a partir da gravação de improvisações; após, realiza edições do áudio gravado, gerando um fonograma final que considera como uma comprovisação. Novamente, podemos perceber uma semelhança, em aspectos, à compreensão de Trevor Wishart sobre improvisação lenta - a improvisação como geradora de material para composições. Podemos traçar algumas críticas à compreensão de Hannan dado que o aspecto primário para a criação de comprovisações, em sua visão, é a gravação de improvisações livres. A produção de um acervo sonoro, como supramencionado, é realizada a partir de direcionamentos realizados pelo próprio autor em busca de sonoridades possíveis para serem utilizadas na edição final da peça. Como exemplo, descreve o processo de criação da peça denominada Whale Dance, na qual pequenas bolas de vidro são lançadas aleatoriamente nas cordas de um piano; este processo é repetido inúmeras vezes alterando-se certos parâmetros: velocidade das bolas, dinâmica, possibilidades de timbre e alturas. Este processo é gravado e posteriormente analisado para que o compositor possa escolher, dentre este acervo, as sonoridades que deseja utilizar na edição final da peça.

A crítica que buscamos traçar aqui se refere à compreensão do autor deste processo como improvisações livres prévias. Ao apresentarmos alguns conceitos referentes às práticas de livre improvisação, destacamos que esta, sinteticamente, é uma prática na qual há uma criação musical espontânea sem a existência de um referente prévio. Porém, este referente não é inexistente: segundo a hipótese de Costa e Schaub (2013), este referente é gerado em tempo real a partir da interatividade do grupo, o que gera uma direcionalidade para a performance de acordo com os desejos individuais que, em consequência, geram uma emergência que reflete o caráter complexo da livre improvisação - o referente temporário que mencionam Costa e Schaub (2013) pode ser compreendido, portanto, como um elemento emergente (FARACO, 2020).

Em Hannan, tal processo de criação de referentes temporários nos parece inexis-

5 Cabe uma ressalva sobre processos criativos que envolvem a interação por meio da improvisação e de suportes tecnológicos. Este debate não engloba somente a visão de comprovisação, mas também está inserido no que Chadabe (1984) considera como composição interativa (CHADABE, 1984; BRESSON e CHADABE, 2017). 
tente. Não há ações volitivas do improvisador para a criação de uma direcionalidade formal, musical, ou seja, um resultado sonoro satisfatório para o improvisador - um dos objetivos da livre improvisação, como mencionam Canonne e Garnier (2015b). O que há é uma exploração sonora em busca de elementos musicais que auxiliarão o compositor em um próximo passo - a edição. Por isto, é que vinculamos tal processo criativo de Hannan à compreensão de Wishart sobre improvisação lenta. Este não é um processo criativo espontâneo que tem como fim ela mesma, mas é direcionada a passos posteriores do processo: a saber, no caso de Hannan, a edição final da peça. Portanto, cabe questionar se tais peças poderiam ser consideradas como comprovisações em seus próprios termos, dado que o autor caracteriza tal prática como a coexistência de processos criativos improvisatórios e composicionais. Em semelhança à compreensão de Hannan, Coleman (2016) baseia-se no trabalho de seu grupo voltado à prática de free jazz: após gravações de sessões de improvisação, há uma edição de áudio resultando em um fonograma que difere da improvisação original. Há, no trabalho destes autores, uma predominânica de peças "eletrônicas", sem possibilidades de atualizações posteriores por músicos em performances.

A segunda vertente, que nomeamos Comprovisação como descrição abrangente de práticas musicais abertas, tem como base o uso do termo para explicitar características de peças musicais que possuem atributos normalmente considerados como "aberturas", delegações criativas ao intérprete para que este seja atualizador da obra. Partimos do que consideramos uma visão sintética das visões dos autores que reunimos nesta vertente, sendo que a comprovisação abrangeria um "espectro de métodos de criação musical que atingem tanto um alto grau composicional quanto um grau relativamente alto de ação do intérprete, liberdade, espontaneidade e flexibilidade" (DALE, 2008, p. 5, tradução nossa). Esta compreensão de um espectro pode ser relacionada com as já mencionadas visões de Nettl e Russel (1998) e Canonne (2018a) e suas compreensões do contínuo de práticas musicais. Parece-nos que, em um primeiro momento, para autores da segunda vertente, comprovisação seria este termo amplo que abarcaria diversas práticas inseridas ao longo deste espectro. Ainda de acordo com Dale (2008, p. 6-7), se diferenciariam da composição e da improvisação tanto em definição quanto em características de identidade e variabilidade, dado que na comprovisação "uma ou mais pessoas predeterminam somente partes de como uma peça musical será; o resto é determinado no momento da perfomance ou execução". Além disto, a comprovisação "pode ser repetida com graus maiores ou menores de variabilidade e manter uma identidade reconhecível" (DALE, 2008, p. 6-7, tradução nossa).

Acreditamos que a compreensão de Sandeep Bhagwati (2013) seja fundamental para o que consideramos ser esta segunda vertente de entendimento sobre comprovisação. O autor busca, a partir de estudos etnomusicológicos e da noção de musicar, de Christopher Small (2008), compreender como diferentes tradições musicais utilizam a notação para definir elementos independentes de contexto - aqueles que permanecem inalterados na execução de uma peça (como notas em uma pauta com altura, rítmica e dinâmica definidas) - e elementos contingentes - aqueles que poderiam ser considerados como aberturas, de acordo com o que certa tradição consideraria como 
esteticamente relevante. Portanto, em cada tradição do musicar, há uma valoração (ou parametrização) dos elementos notados; por meio dessa, surgem "níveis de aberturas" em peças musicais. Novamente, assemelha-se à compreensão de Nettl e Russel (1998) e Canonne (2018a) - o espectro ou contínuo de práticas musicais em que se opõe [porque não "práticas musicais em que se complementam"] a composição totalmente escrita e a improvisação totalmente livre. Em síntese:

\begin{abstract}
Práticas [...] que possuem esta inter-relação conscientemente adotada, foram denominadas como "improvisação estruturada" (Malcolm Goldstein e outros), "conduction" (Butch Morris), "game pieces" (John Zorn), "indeterminação" (John Cage), "música intuitiva" (Karlheinz Stockhausen) ou "aleatoriedade limitada" (Witold Lutoslavski). No entanto, todos estes termos foram cunhados para descrever uma prática criativa específica e permaneceram em grande parte confinados a ela; por vezes, utilizados como um meio de demarcação por parte do discurso dominante da tradição eurológica centrada na relação compositor/ partitura (BHAGWATI, 2013, p. 170, tradução nossa).
\end{abstract}

Com isto, a comprovisação estaria vinculada às práticas inseridas ao longo deste espectro, tendo em vista sua compreensão de acordo com cada tradição de musicar e a respectiva valoração dos elementos notacionais. Em acordo com sua visão sobre comprovisação, Bhagwati cria o que considera uma ferramenta analítica para comprovisações. Esta, denominada perspectiva notacional, consiste em categorias de análise de notação musical (que serão abordadas adiante), a fim de demonstrar as valorações existentes entre elementos independentes de contexto e contingências.

Outros autores utilizam da compreensão de Bhagwati sobre comprovisação para descrever seus trabalhos artísticos. Como exemplo, Papageorgiou (2015, p. 100) busca “iniciar um diálogo entre práticas improvisatórias e composicionais e pontos de vista teóricos ocidentais/orientais" a partir da noção de seyir e da criação de possibilidades sonoras que denomina como sound gestures, gerados a partir de dois momentos: improvisação - transcrição; transcrição - comprovisação. Desta forma, cria notações a partir de improvisações prévias, delimitando elementos independentes de contexto e possíveis contingências, vinculando-se desta forma à compreensão de Bhagwati, devido à função da notação como representante da geração de um possível diálogo entre composição e improvisação, como mencionado. Obijiaku (2019) também parte das compreensões de Bhagwati para caracterizar as práticas em corais ICAM (Ibgo Choral Art Music), inserido na tradição nigeriana Igbo, como comprovisações, dado que diversos elementos desta prática não são notados, porém realizados em performances tradicionais. Pode-se argumentar, de acordo com o autor, que o uso da improvisação nesta prática está vinculado à tradição oral - e o ensino das peculiaridades da interpretação de peças inseridas em tal tradição -, dado que partes não notadas seguem aspectos preestabelecidos da compreensão melódica sobre o texto coral, que envolvem liberdades de escolha.

Nesta que consideramos como a segunda vertente de compreensões sobre a comprovisação, inserimos também pesquisas acadêmicas brasileiras sobre a prática, como o trabalho de Aliel (2017). Seu trabalho, que envolve comprovisações a partir de conceitos 
da ecologia sonora, ${ }^{6}$ tem influência de alguns autores aqui citados, como Dudas (2010), Mailman (2013) e Hannan (2006). Porém, em nossa análise, acreditamos que sua visão sobre comprovisação tenha bases na visão de Bhagwati, dado o que compreende como planos de diretrizes e planos de contingências. O primeiro consiste em ações previstas em tempo diferido - ou seja, elementos independentes de contexto; o segundo, as imprevisibilidades e acasos existentes nas performances (relacionado às contingências) (ALIEL, 2017, p. 38). Desta forma, Aliel propõe formalizações de modelagens ${ }^{7}$ de comprovisações para performances com características da ecologia sonora ${ }^{8}$.

\section{Comprovisação como "jogo": o pacto e os fluxos de interpreta- ção e improvisação}

A multiplicidade de visões sobre o termo comprovisação é demonstrativa da problemática mencionada no início: não há um consenso na literatura sobre sua definição. Porém, percebe-se que para estas possíveis compreensões aqui elaboradas, há um ponto de partida em comum: uma análise a partir do processo criativo. Ou seja, os autores elaboram suas propostas a partir de seus pontos de vista como criadores de uma peça musical que possui aberturas à improvisação (ou a utilizam como material gerativo). A partir deste viés, desejamos, a fim de uma colaboração neste debate sobre o significado de comprovisação (e como, posteriormente, atrelaremos as peças analisadas a esta compreensão), olhar a partir da perspectiva do ouvinte (sua percepção ao deparar-se com uma comprovisação) e também por uma visão sobre a performance: como o músico realiza ações em uma peça com características comprovisadas.

Buscamos esta compreensão com foco no ouvinte ao nos depararmos com uma questão perceptiva relacionada à composição e à improvisação. Lehmann e Kopiez (2010) possuem a hipótese de que, ao se deparar com uma peça, a percepção do apreciador não direciona sua escuta a elementos compostos ou improvisados. Na realidade, a escuta seria direcionada mais a uma "estilística" - percepção de estilos musicais que se relacionariam com a peça apreciada. Os autores, por meio de um experimento empírico controlado, perceberam que há uma certa dificuldade por ouvintes em discernir se peças são compostas ou improvisadas se não há alguma contextualização prévia. Em concordância, Canonne (2018b) realiza um experimento em que dá esta contextualização aos ouvintes, e pede que estes qualifiquem a obra - suas percepções, se acreditam que aquela peça é satisfatória, as qualidades e defeitos, entre outros. O resultado pos-

\footnotetext{
6 Para o autor, esta é compreendida como "a subjetividade sonora de um lugar captada e interpretada pela percepção dos agentes" (ALIEL, 2017, p. 38).

7 Como exemplo destas modelagens, o autor cita: o uso de layerings (polifonia sonora em camadas); uso de "fluxogramas como opções de recurso composicional" (2017, p. 37); construção de ferramentas tecnológicas para a improvisação, similar às concepções de Dudas (2010) e Mailman (2013). Desta forma, por meio de tais modelagens, o autor considera que planos de diretrizes e planos de contingências podem ocorrer concomitantemente em uma performance.

8 Uma performance artística que se baseia na visão de Aliel (2017) sobre comprovisação que achamos de interesse destacar é a realizada por Antar e Oliveira (2017), nomeada TransPosições. Desenvolvida com atores, atrizes e um grupo de músicos improvisadores na cidade de São Paulo, a performance tem como princípio a improvisação musical e a improvisação cênica baseada em um texto literário, e tem como base o uso de planos de diretrizes - momentos da performance já delimitados -, e planos de contingências - momentos de improvisação que partem tanto do texto quanto dos elementos da performance em si.
} 
sui uma relação com o trabalho de Lehman e Kopiez: foi executada uma improvisação livre com características composicionais a dois grupos distintos. Para um dos grupos, foi mencionada que esta peça, na realidade, era uma composição totalmente notada e executada por intérpretes. Já para o segundo grupo, a peça foi descrita como uma livre improvisação. No grupo em que a peça foi definida como uma composição, surgiram diversas críticas à estruturação da peça e às escolhas realizadas pelo compositor; já no grupo em que a peça foi apresentada como uma improvisação, os ouvintes direcionaram sua escuta mais para uma percepção da interação do que à qualidade estrutural da peça em si.

Acreditamos que esta dificuldade no discernimento entre composição e improvisação, além dos diferentes julgamentos qualitativos realizados quando há uma contextualização prévia sobre uma peça musical, é representante daquilo que Falleiros (2012, p. 74) denomina como pacto. Nas palavras do autor,

\begin{abstract}
A narrativa ficcional lança o acontecimento para o espaço da especulação. Para isso, é necessário que o 'leitor' desta narrativa se desprenda da referência racional que exige provas externas e universais e imerja na particularidade própria do mundo ficcional, estabelecendo assim um pacto com a obra. Uma narrativa que pretenda descrever um acontecimento no seu instante presente, por sua vez, deveria ser formulada pelo embate constante do refazer e reorganizar que se sucederia do encontro entre a narrativa racional e a ficcional. Construir uma narrativa que pretenda apresentar o acontecimento presente, como a improvisação, necessita que primeiramente seja feito um relato do entendimento da relação da poética com a observação, e por conseguinte das idiossincrasias de cada fazer artístico.
\end{abstract}

Ou seja, os diferentes julgamentos qualitativos demonstrados na pesquisa de Canonne (2018b) não são meras descontextualizações do ouvinte, mas uma alteração do pacto, sendo que, para a formulação de tais julgamentos, aquele que escuta busca suas referenciações no que conhece como as idiossincrasias das práticas. A partir do momento em que este pacto não é estabelecido, há uma dificuldade de discernimento sobre a apresentação material do fazer artístico. Em práticas inseridas na estética da indeterminação, no free jazz ou improvisações livres, há pactos que são realizados que visam a um "aceite" da abertura como intrínseca ao fazer artístico. O que consideramos passível de diferenciar a comprovisação é que este pacto, na realidade, é desestabilizado, ocorrendo então um "jogo" com o ouvinte, sendo que este não consegue diferenciar momentos com elementos independentes de contexto e contingências. Diferentemente das práticas mencionadas, em comprovisações este pacto tem como objetivo esta desestabilização, valorizando uma certa permeabilidade entre processos composicionais e improvisatórios.

Ao analisarmos a compreensão de pacto a partir da hipótese levantada por Lehmann e Kopiez (2010), percebemos a necessidade de uma contextualização prévia ao ouvinte para que este possa discernir entre os processos ocorrentes em sua audição de uma peça específica. Sem esta contextualização, ainda de acordo com a hipótese destes autores, a percepção é direcionada a uma escuta "estilística". Devemos levar em conta que esta escuta estilística também engloba, às vezes, um possível discernimento entre o que 
seria caracterizado como composição e improvisação - o que remete, novamente, ao pacto. A "narrativa ficcional" apresentada por uma peça inserida em um certo contexto - como, por exemplo, um standard de jazz tradicional - possui como elemento característico a improvisação sobre chorus. Portanto, apesar de o experimento controlado de Lehmann e Kopiez nos direcionar a uma compreensão de possíveis impossibilidades existentes no discernimento entre materiais composicionais e improvisados, devemos levar em conta a contextualização prévia (como exibido nos experimentos de Canonne [2018]), que pode não somente se referir diretamente ao material (elementos independentes de contexto ou contingências, nos termos de Bhagwati [2013]), mas também ao contexto estilístico no qual a peça se encontra.

Portanto, o que chamamos de desestabilização do pacto refere-se à possibilidade do entendimento da comprovisação como um jogo que busca alterar a percepção do ouvinte, compreendendo a dimensão volitiva que esta possui. Ou seja, o ouvinte busca, como demonstrado nos experimentos supracitados, compreender a peça em determinado estilo ou, no caso de uma contextualização com caráter voltado ao material, compreender os elementos da peça que possam ser compostos ou improvisados. A comprovisação, em nossa visão, busca uma permeabilidade destes elementos, além de não necessariamente se enquadrar especificamente em um "estilo" ou "idioma" convencional. Desta forma, há a possibilidade - assim como em práticas de improvisação livre - de o ouvinte ter parte da construção da peça. Ao jogar com a percepção, uma comprovisação caracteriza-se pela possibilidade de quebra de intencionalidades ao adentrar no campo da livre improvisação mas, ao mesmo tempo, pode possuir elementos temáticos, construções de caráter composicional, entre outros.

Além desta compreensão sobre a percepção do ouvinte, buscaremos analisar o que chamamos de desestabilização do pacto por meio de elementos da performance, quando analisados por meio da compreensão de processos generativos (CLARKE, 2001), sendo estes possíveis representações de uma estrutura musical e a provocação que gera no sistema motor do músico. Clarke (2001, p. 4) propõe uma possível visualização destes processos por meio de "níveis" hierárquicos de elementos de uma peça pelos quais o intérprete se guiaria e teria respostas motoras. Como exemplo, o autor propõe uma idealização de como se daria uma interpretação: 
Fig. 1: Representação esquemática de uma estrutura de conhecimento para uma performance musical memorizada. Fonte: Clarke (2001, p. 4).

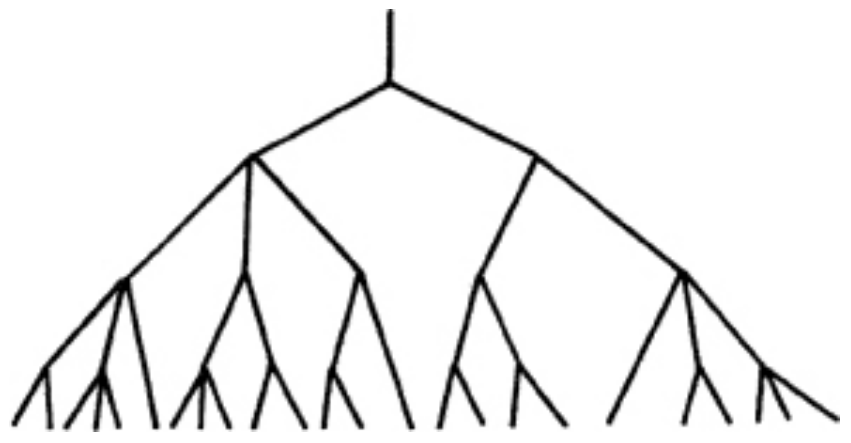

Os níveis superiores indicariam macroelementos da peça necessários para que o músico realize uma interpretação que considere satisfatória - uma visão panorâmica -, incluindo aspectos como caráter harmônico-rítmico-melódico, transições existentes, inserção da peça em uma poética específica, entre outros. Os níveis inferiores seriam vinculados a elementos específicos de partes da música, como caráter melódico de uma certa parte, expressão, dinâmica e articulações. Há, na idealização de Clarke, acessos constantes aos elementos tanto de nível superior quanto de nível inferior. Desta forma, o intérprete teria total consciência sobre os elementos da peça, que influenciam sua maneira de tocar. ${ }^{9}$

Seguindo o modelo de Clarke, o processo generativo de uma improvisação diferenciar-se-ia do da interpretação devido aos possíveis acessos aos níveis. Processos improvisatórios podem não prescindir de hierarquizações preestabelecidas, sendo que a improvisação caracterizar-se-ia pela concatenação de eventos:

Fig. 2 - Representação esquemática de uma estrutura de conhecimento para uma performance improvisada. Fonte: Clarke (2011, p. 11)

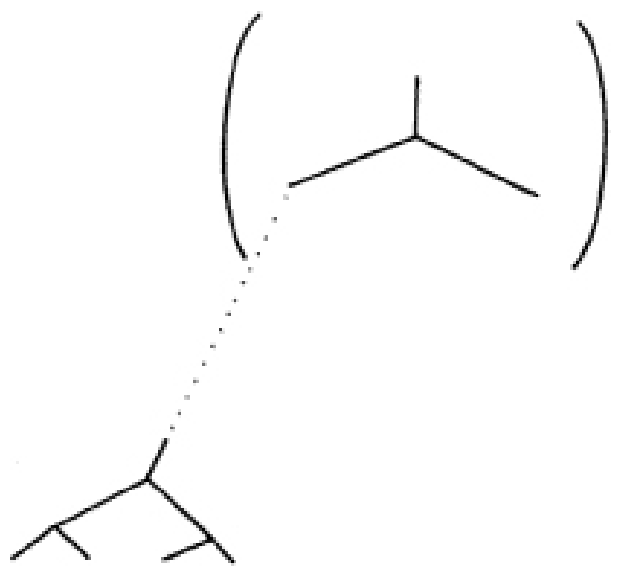

9 Clarke (2001) a caracteriza como uma idealização dado que, na realidade, o intérprete não teria acesso a todo momento a todas as representações dos processos generativos. 0 que o autor considera que ocorre é um acesso intermitente entre as estruturas hierárquicas, sendo que o acesso a níveis superiores só ocorreria em partes em que tal acesso é realmente necessitado (CLARKE, 2001, p. 6). 
Estes eventos podem ser sequenciados por meio de três formas:

(1) O primeiro evento pode ser parte de uma estrutura hierárquica, criada anteriormente até certo ponto, e construída ao longo da improvisação até certo ponto [...]. (2) O primeiro evento pode ser parte de uma cadeia associativa de eventos, em que cada novo evento deriva da sequência anterior por meio de uma transferência direta de informações [...]. (3) O primeiro evento pode ser selecionado a partir de um número de eventos constituídos no repertório do intérprete, sendo que a construção da improvisação consistiria em outras seleções deste mesmo repertório, com um grau de relação variável entre tais seleções [...]. (CLARKE, 2001, p. 11, tradução nossa).

Ao analisarmos a comprovisação por meio da noção de desestabilização do pacto, como um "jogo" com a escuta do ouvinte em que este não discerne estritamente sobre elementos improvisados e compostos, podemos inferir que, ao longo de uma performance, ambos os processos generativos existiriam. Ou seja, o intérprete possui acesso a níveis superiores, porém tem possibilidades de abandoná-los tendo em vista o início de uma concatenação de eventos improvisados. Consideraremos esta abordagem como uma interligação entre os fluxos: da interpretação e da improvisação. Desta forma, em nossa visão sobre comprovisação, a mencionada desestabilização surge a partir do momento em que estes fluxos não são aparentes - eles, por meio das possibilidades da peça e das ações dos intérpretes, interligam-se.

\section{Laboratório de Criação}

O trabalho criativo que aqui será debatido foi fruto de uma colaboração entre o autor e o Coletivo Improvisado, grupo de pesquisa e prática de livre improvisação vinculado à Unicamp, sob coordenação do Prof. Dr. Manuel Falleiros. Ao longo do segundo semestre de 2019, entre os meses de agosto e dezembro, foram realizados encontros semanais para prática e discussão sobre a livre improvisação coletiva. Foi a partir destes encontros que surgiram as primeiras ideias para a realização de experimentos em comprovisação. As quatro peças resultantes desta colaboração foram apresentadas em concerto nomeado Quatro Peças para Improvisadores, realizado no dia 22 de novembro de 2019 na Casa do Lago, situada na Unicamp. ${ }^{10}$

Buscaremos realizar nossa análise das peças criadas a partir de três pontos principais: 1) sua relação com as compreensões sobre comprovisação descritas anteriormente; 2) por meio da perspectiva notacional de Bhagwati (2013), a fim de compreender a função da notação; 3) as possibilidades de desestabilização do pacto e a interligação de fluxos de interpretação e de improvisação, por meio de uma visão empírica sobre as diferentes performances (ensaios e concertos).

Para compreendermos nosso segundo ponto de análise, a perspectiva notacional, discorreremos brevemente sobre as categorias analíticas levantadas por Bhagwati

10 A gravação da performance integral é pública e está disponível no link: https://www.youtube.com/watch?v=NOUqq|2CJbg\&list=PLqEJekh119melCa99ohdNI2hHVOhk1RRc 
(2013), para que se possa delimitar os elementos independentes de contexto e as contingências das peças por meio da notação. Tais categorias são: estilos de notação, objetos notacionais, relações internas, funções, graus de abertura e impossibilidades. ${ }^{11} \mathrm{~A}$ primeira categoria refere-se aos diferentes tipos de notação, sendo que, para o autor, estas podem ser consideradas como nêumica (sinais mnemônicos que dão suporte ao intérprete em parâmetros como entonação e articulação), simbólica (desenvolvida a partir da inscrição dos neumas em uma pauta musical), gráficas (que busca uma sinalização totalizante do evento sonoro) e a textuais (considerada extensão da notação simbólica devido, ocasionalmente, à falta de uma representação icônica de uma ação, sendo portanto descrições literais de um evento) (BHAGWATI, 2013, p. 172).

Os objetos notacionais seriam as demarcações existentes na partitura, sejam elas notações simbólicas, gráficas ou textuais - ou seja, os objetos referem-se a como a música é inscrita na notação. Como relações internas, o autor busca compreender como os diferentes objetos notacionais ou estilos diversos de notação se influenciam mutuamente. Após esta verificação dos objetos notacionais e suas relações, cabe uma descrição sobre suas funções - o que estes representam para a peça musical. Isto nos leva aos dois últimos parâmetros: graus de abertura, caso algum objeto notacional ou o próprio estilo de notação (ou a omissão de notações) tenha como objetivo a geração de contingências, e as impossibilidades, que se referem aos elementos independentes de contexto.

\section{1 insígnia}

A peça insígnia, para saxofone barítono ou clarone, contrabaixo e piano, teve como sua base de criação a gravação de improvisações livres realizadas pelo grupo Coletivo Improvisado. Posteriormente, foi realizada uma seleção do material gravado e uma edição, gerando um fonograma. Este foi transcrito (por meio da notação tradicional) e, por fim, executada pelo grupo. Possui influência dos trabalhos de Hannan (2006), ${ }^{12}$ dado que o processo criativo possui dois momentos: a gravação de improvisações e a seleção de material, e a edição posterior deste. Também há influência do trabalho de Rapson (MISTERY..., 2011), sendo que esta edição posterior é transcrita e executada pelos músicos.

Seguindo a perspectiva notacional, há na peça a predominância do estilo de notação simbólica, sendo os objetos notacionais notas marcadas na pauta com alturas, rítmicas, dinâmicas e expressões delimitadas. As relações internas dos objetos notacionais são representadas por suas funções: demarcar os momentos de execução das notas especificadas, além das maneiras de execução. Desta forma, o grau de abertura é

\footnotetext{
11 Em seu texto, Bhagwati elenca sete categorias. A sexta categoria, que denomina como "impacto na experiência estética", não será abordada devido às nossas considerações de que não há como analisar, por meio da notação, tal impacto. Primeiramente, não há foco, pois a experiência estética é percebida por diversas partes (compositor - intérprete - ouvinte). Além disso, uma análise dessa experiência seria generalizada, o que não é real, dado que esta pode ser compreendida como subjetiva.

12 Ressalta-se que outro experimento em comprovisação foi realizado a partir das visões de Dudas (2010) e Mailman (2013), culminando na peça à deriva. A análise desta peça consta no trabalho de Faraco e Falleiros (2019); portanto, a compreensão sobre comprovisação que remete ao processamento de áudio em tempo real não foi abordada nas peças aqui analisadas.
} 
mínimo, dado que não existem contingências ao intérprete; este possui mínimas possibilidades de variação, como interpretação sobre andamento, dinâmicas e expressão. Por fim, as impossibilidades são relacionadas às próprias contingências, dado que estas não são existentes.

Exemplificando o que foi supracitado, um trecho da peça é representativo:

Fig. 3 - Excerto da peça insígnia.

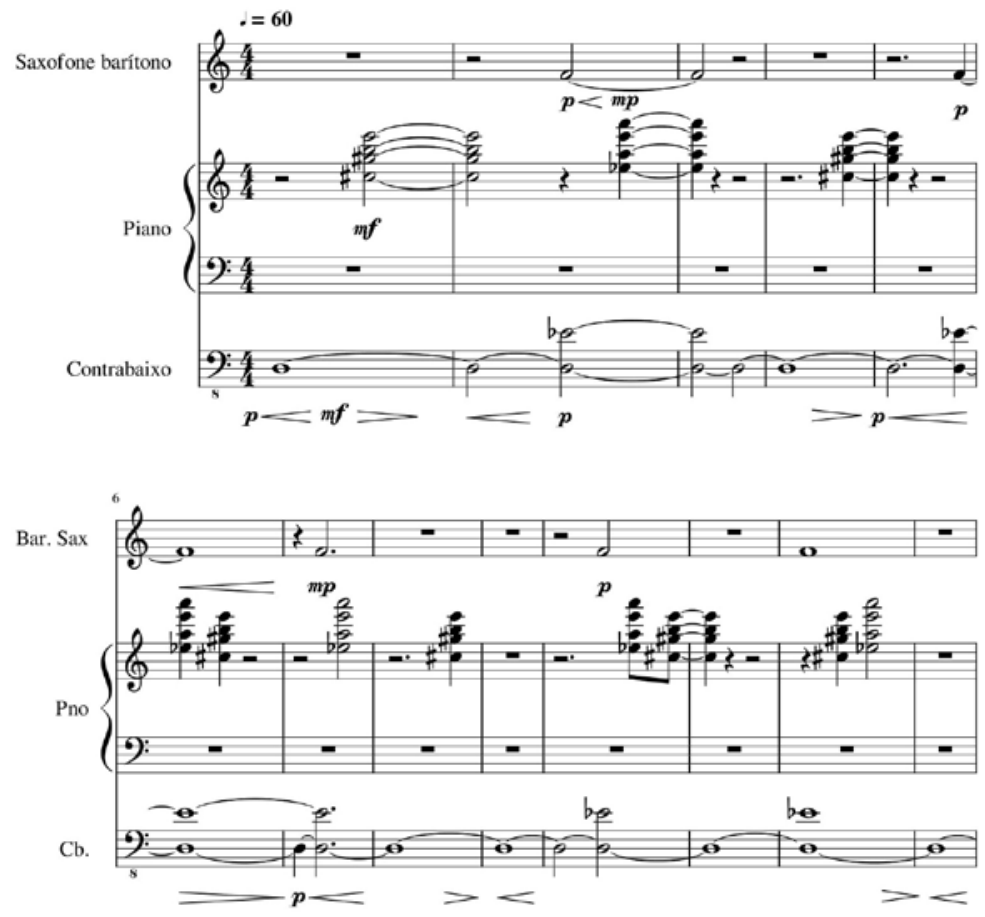

Fonte: Elaboração própria.

A transcrição literal do fonograma por meio da notação simbólica delimita as possíveis ações dos intérpretes ao longo da execução da peça. Pequenas variações em elementos que não descaracterizam a identidade temática da peça foram realizadas: variações de andamentos, entradas, dinâmicas. Ao levarmos em conta os ensaios realizados e as apresentações da peça, percebemos que não há, efetivamente, um processo perceptivo que possua a característica de uma desestabilização do pacto. A peça caracteriza-se como uma composição de caráter "fechado": seguindo critérios qualitativos sobre a composição descritos em Canonne (2018b), possui uma estrutura formal, com repetições temáticas delimitando uma forma clara. Além disso, a performance, restrita ao material consolidado na partitura, não possibilita aos intérpretes possíveis improvisações. Mesmo a peça possuindo influências dos trabalhos de Hannan (2006) e Rapson (MISTERY..., 2011), como mencionado, seguindo um processo "tripartido" - improvisações livres - edição e fonograma e transcrição -, a improvisação na performance é inexistente. Portanto, cabe questionar se realmente esta peça se caracterizaria, de acordo com nossa definição aqui levantada, como uma comprovisação. Pensando-se nos elementos de desestabilização do pacto e da interligação dos fluxos na performance, 
podemos aferir que não é representativa da prática.

\section{2 escafandro}

Buscamos, na peça escafandro, para saxofone barítono, clarone, contrabaixo e piano, testar elementos como aleatoriedade, indeterminação e uso da notação gráfica para perceber se há, realmente, possibilidades improvisatórias em peças que se valem de tais materiais. Partimos inicialmente das compreensões da segunda vertente que delimitamos sobre comprovisação: um termo que abarcaria práticas inseridas na estética da indeterminação ou que englobaria processos criativos inseridos no espectro de Nettl e Russel (1998) ou a compreensão de contínuo de práticas, de Canonne (2018a). Desta forma, almejamos analisar as possibilidades que a notação gráfica permite, e se esta gera contingências suficientes para percebermos a existência de um fluxo de improvisação e a desestabilização do pacto. O processo criativo da peça tem uma base semeIhante à de insígnia: a gravação de improvisações livres realizadas pelo grupo, a seleção de material a ser utilizado, uma edição do áudio visando à criação de um fonograma e, por fim, a transcrição deste.

Porém, diferentemente de insígnia, em escafandro buscamos não transcrever literalmente o fonograma, visto que almejávamos o uso de aleatoriedades e indeterminações. Portanto, utilizamos de uma ferramenta nomeada por Stone (1980) como hard boxes. Tal ferramenta é utilizada principalmente em peças de Pierre Boulez, com objetivo da introdução da aleatoriedade em sua obra (TRENKAMP, 1976). Em escafandro, este material é utilizado a fim de que o intérprete possua uma escolha em determinados trechos da peça. Como exemplo do uso de hard boxes:

Fig. 4 - Excerto de escafandro: uso de hard boxes.

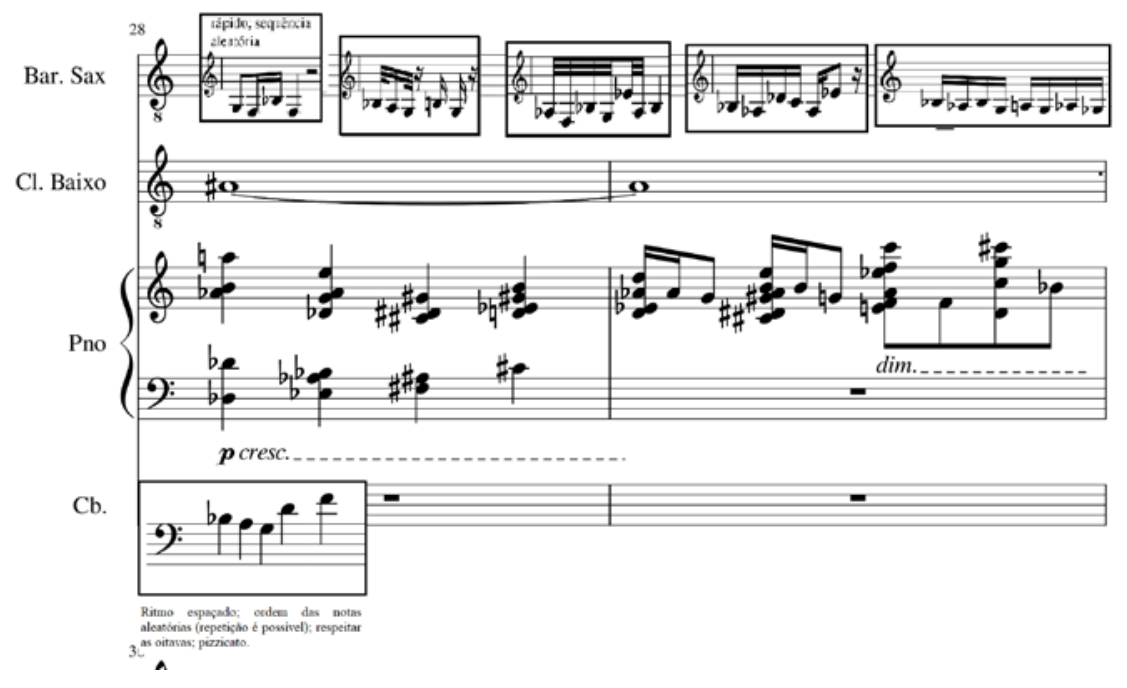

Fonte: Elaboração própria. 
As hard boxes presentes no exemplo acima possuem seu material derivado das improvisações livres transcritas previamente. No momento em que o intérprete se depara com tal material, ele deve escolher, dentre uma das caixas presentes, uma específica para executar ao longo do tempo determinado. Representa, portanto, possibilidades ou caminhos para o intérprete. Na obra de Boulez, como descrito por Trenkamp (1976), o uso desta ferramenta composicional altera um princípio de reprodutibilidade da peça; porém, o controle sobre o direcionamento final da composição ainda está sob o domínio do compositor, dado que este previamente delimita todos os possíveis caminhos sem que ocorra uma perda de identidade da peça (BOULEZ, 1974; TRENKAMP, 1996).

Já as indeterminações são apresentadas a partir de notações gráficas inseridas na pauta:

Fig. 5 - Excerto de escafandro: uso de indeterminações.

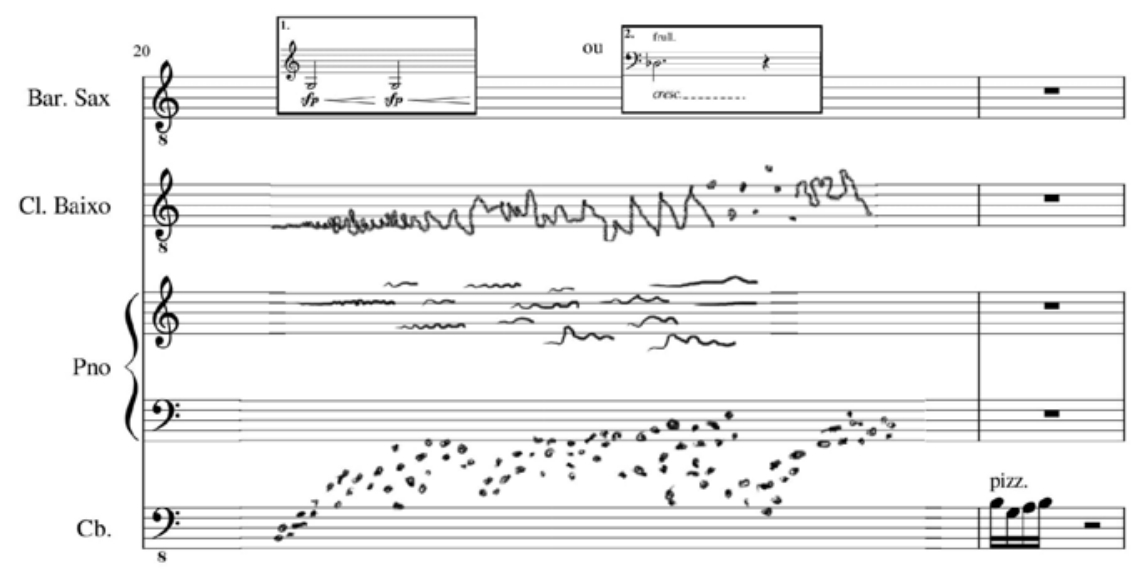

Fonte: Elaboração própria.

A notação gráfica aqui apresentada possui o mesmo princípio da criação das hard boxes e da criação da peça em si: uma maneira de transcrição das edições de improvisações livres realizadas previamente. É claro que, através de uma transcrição por meio da notação gráfica, busca-se representar o material transcrito de uma maneira diversificada daquela através da notação simbólica: ou seja, há uma liberdade na transcrição que por sua vez é refletida na execução e na apreensão desta notação. Nosso objetivo, com o uso desta notação gráfica, foi o de determinar a influência que ela exerce no momento de interpretação, e se esta poderia caracterizar um perfil improvisado durante a peça.

Analisando-se mediante a perspectiva notacional, percebe-se que há os estilos de notação simbólica, gráfica e textual. Como objetos notacionais, temos notas inseridas na pauta com altura e rítmica definidas, além de articulações, expressões e dinâmicas; "caixas" com notação simbólica que representam escolhas para o intérprete; linhas e grafismos representando um evento específico que tem um caráter indeterminado. Estes objetos notacionais se complementam, tendo relações internas que são inerentes à compreensão da execução dos grafismos existentes (como as hard boxes). A notação simbólica tem como função principal delimitar algumas das ações do intérprete; já as notações gráfica e textual têm como funções principais demarcar a existência de con- 
tingências na peça, e possibilitar ao intérprete a escolha do material a ser executado. Com isto, temos um grau de abertura referente a tais elementos notacionais. Por fim, é impossibilitado ao intérprete que este altere as funções da notação simbólica da peça, sendo que tais alterações são restritas às partes em que a notação sugere aberturas.

Iremos nos basear em três diferentes execuções da peça para nossas considerações ${ }^{13}$, a partir de dois pontos principais: as aleatoriedades presentes não demarcam uma mudança formal brusca; a interpretação da notação gráfica é influenciada pelo material executado previamente, gerando características interativas, porém que não se diversificam ao longo das performances. Sobre o primeiro ponto, as aleatoriedades não dão margem para interação explícita entre os intérpretes, e o resultado sonoro final não é alterado drasticamente. Por exemplo, na finalização da peça, o baixo, com um quadro de possibilidades aleatórias, interage explicitamente nas três performances com a rítmica designada ao piano. Isto é consequência das relações internas existentes - o contrabaixista deve estar atento à deixa do piano para a realização do último gesto. Portanto, há um mapeamento realizado pelo compositor, e nenhum dos caminhos tomados pelos intérpretes descaracterizou uma possível reprodução da obra:

Fig. 6: Excerto de escafandro - aleatoriedades e finalização da peça.

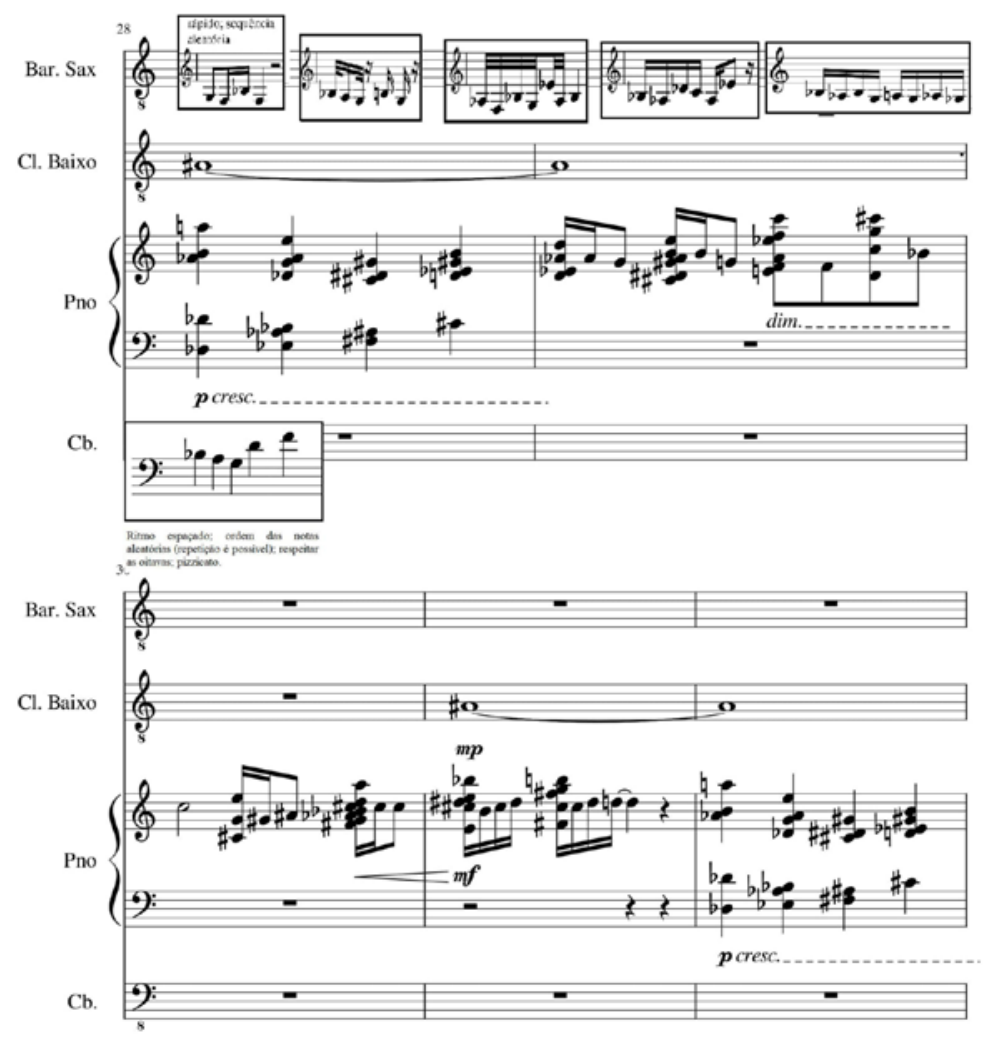

Fonte: Elaboração própria.

13 Realizadas nos dias 15/10/2019, 22/10/2019 e 29/10/2019. 
Outro aspecto relevante é a interpretação da notação gráfica: esta é percebida como o ponto principal de abertura nas performances. Há uma interação característica ao longo da interpretação, em que percebemos como os músicos respondem a gestuais realizados (por meio de imitação gestual ou integração - aspectos observados a partir da visão de Globokar [1970]). Remetem, portanto, a uma prática improvisatória. Porém, percebe-se que, pela delimitação gestual incumbida à notação gráfica, mesmo sendo esta de livre interpretação, há uma resultante na qual as três performances possuem similaridades nos gestos criados. Ou seja, os intérpretes interagem entre si, porém limitados à notação e à indicação do compositor.

Cabe uma compreensão, portanto, sobre as relações entre os possíveis fluxos interpretativos ou improvisatórios nesta peça. A performance não aponta explicitamente para uma interligação de tais fluxos, tendo em vista as impossibilidades que a notação gera. A notação gráfica gera possibilidades interativas com características improvisatórias, porém são respaldadas em dois pontos: a própria notação e o evento posterior ao fim desta parte, que possui uma notação simbólica. Nas performances realizadas, percebeu-se uma confluência entre os intérpretes em uma finalização em conjunto desta parte "indeterminada", dadas as características do evento posterior. Ou seja, há mais uma caracterização de um fluxo interpretativo do que um improvisatório. Porém, tal ideia não é totalizante: coube aos intérpretes esta decisão coletiva. Não significa que, em outras performances, os intérpretes atribuíssem diferentes valores tanto à notação gráfica quanto ao que ela representa na integralidade da peça.

\section{3 sátira}

A peça sátira foi concebida para saxofone barítono, clarone, contrabaixo e piano. Possui um processo similar ao de insígnia, partindo-se primeiramente de uma edição realizada a partir das gravações de improvisações livres realizadas pelo Coletivo Improvisado. O processo de transcrição se deu de uma maneira na qual ocorreram alterações na instrumentação. Por exemplo, elementos materiais retirados de uma improvisação que foram originalmente realizados pelo piano foram transcritos para o saxofone e o clarone. Além disto, foi possível realizar uma edição que gerou um centro tonal, sob o qual é definida uma parte $A$ da peça. Assim, a forma constitui-se de uma parte $A$ (com uma progressão harmônica que gera um centro tonal) e uma parte $B$, na qual esse centro é desconstituído. Há também, ao final da parte B, uma abertura à improvisação; outros elementos formais que constituem a peça são uma parte transitória e aberturas a improvisações livres. Acreditamos que o processo criativo de sátira possui influência do trabalho de Rapson (MISTERY..., 2011), dado a alteração formal existente do fonograma original, por meio de aberturas a improvisações.

Ocorre, portanto, o que consideramos como uma ressignificação do gesto improvisado. Um material, que em primeiro momento é derivado de uma improvisação, torna-se um elemento temático, reprodutível e independente de contexto ao ser editado e executado na peça final. 
Por meio da análise via perspectiva notacional, atestamos que prevalece a notação simbólica, em conjunto com a notação textual. Estas duas práticas de notação possuem como objetos notas demarcadas na pauta que representam altura e ritmo. Já a notação textual possui como objetos frases que demarcam seções específicas da peça. A notação simbólica tem função de especificar os elementos independentes de contexto existentes na peça, como os gestuais que ocorrem no tema. Já a notação textual tem funções múltiplas: primeiramente, define os espaços de abertura à improvisação, seja por meio de um enunciado prescritivo ("improvise livremente"), seja por meio da cifragem. Ambos definem momentos de abertura a improvisação, porém de maneiras diferentes. Além disto, define o referente primário para o início da improvisação no compasso 30 (Fig. 10); por fim, remete às dinâmicas e expressões ao longo da peça. Com isto, conseguimos definir suas relações internas: a notação simbólica, além de definir o tema, delimita possíveis referentes a serem utilizados na improvisação (estes derivados de materiais previamente improvisados); já a notação textual delimita a forma e os momentos nos quais tais referentes podem ser utilizados. Há, portanto, diferentes graus de abertura. O tema definido pela notação simbólica não prevê possibilidades interpretativas que alterem drasticamente o sentido da peça, as possibilidades geradas são alterações de dinâmica e andamento. Os graus de abertura são principalmente derivados da notação textual. A primeira improvisação possui sua duração e seu material definido pelo texto, por meio de cifragem e um enunciado prescritivo. A segunda improvisação é iniciada por meio da desfragmentação, notada textualmente, da célula melódica e rítmica notada simbolicamente. Além disto, há o enunciado prescritivo "improvise livremente". Similarmente, a finalização da peça se dá por meio do mesmo enunciado. As impossibilidades que a notação produz são advindas da notação simbólica.

As aberturas para improvisações ocorrem em três momentos: o primeiro, após a exposição do tema, ocorre a partir da harmonia gerada na parte A. Inicia-se com um acompanhamento notado, referente ao acompanhamento desta mesma parte. Com isto, o saxofone e o clarone improvisam sob a harmonia notada. Após, o acompanhamento não é notado, ficando livre para que o contrabaixo e o piano acompanhem interagindo com os improvisos ocorrentes. Para demonstrarmos, o tema constituinte da parte A é: 
Fig. 7 - Parte A de sátira

sátira
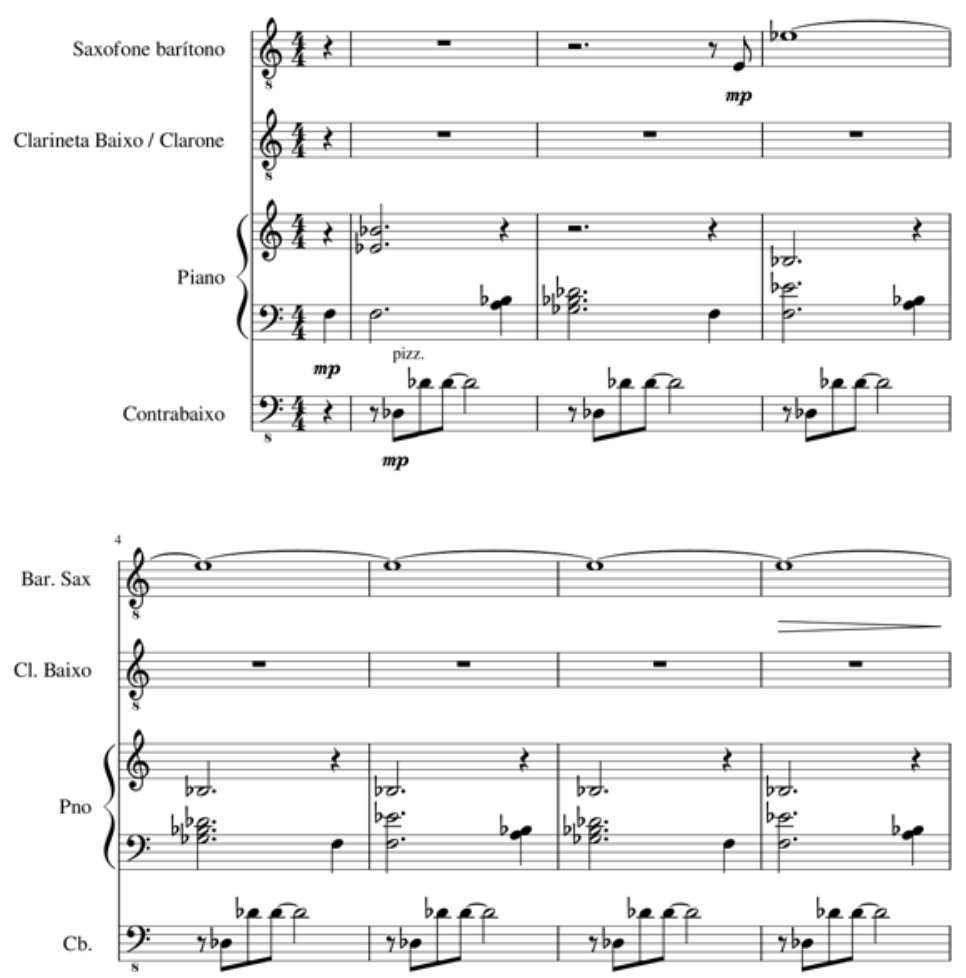

Fonte: Elaboração própria.

A parte B constitui-se a partir de um material que desconstitui o centro tonal gerado:

Fig. 8 - Parte B de sátira.

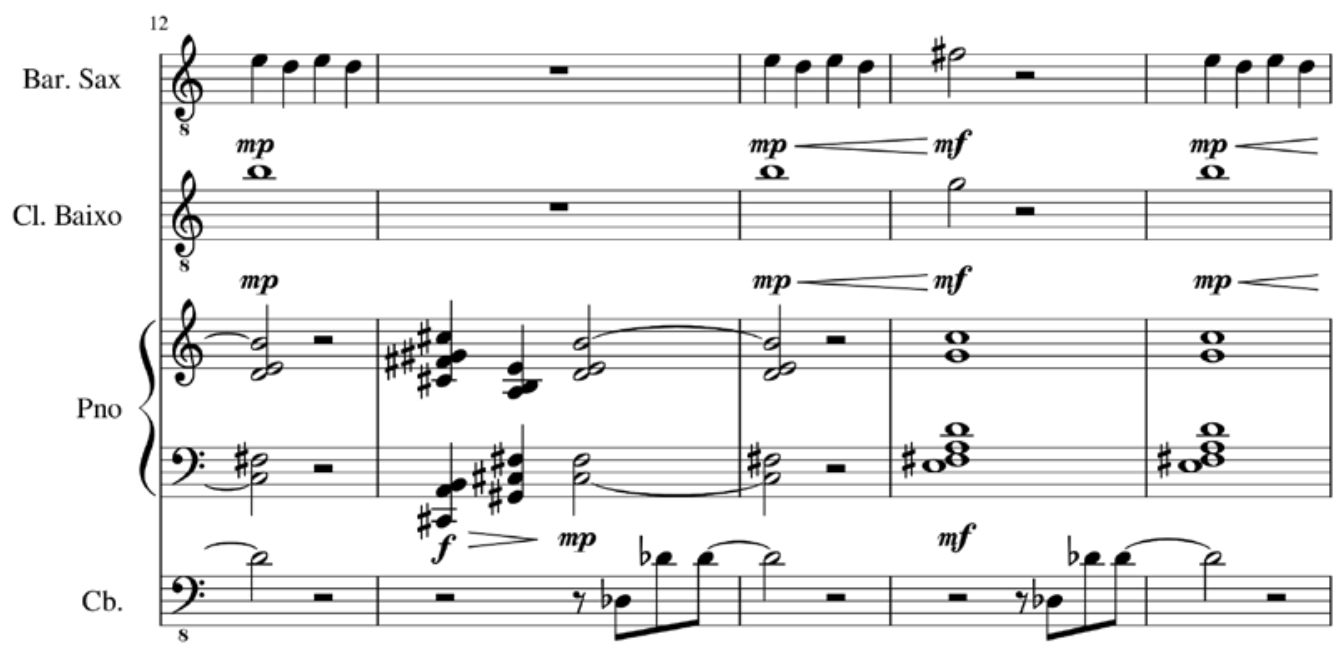

Fonte: Elaboração própria. 
Atribuímos ao tema A um centro tonal em sol bemol, tendo o baixo uma figura melódica e rítmica em ré bemol, invertendo o acorde. Este mesmo pedal continua no tema $\mathrm{B}$, porém o centro tonal é destituído devido aos acordes do piano e à melodia ocorrente no saxofone barítono e no clarone. Ao final do tema $\mathrm{B}$, há a primeira abertura à improvisação.

Fig. 9 - Primeira abertura à improvisação em sátira.

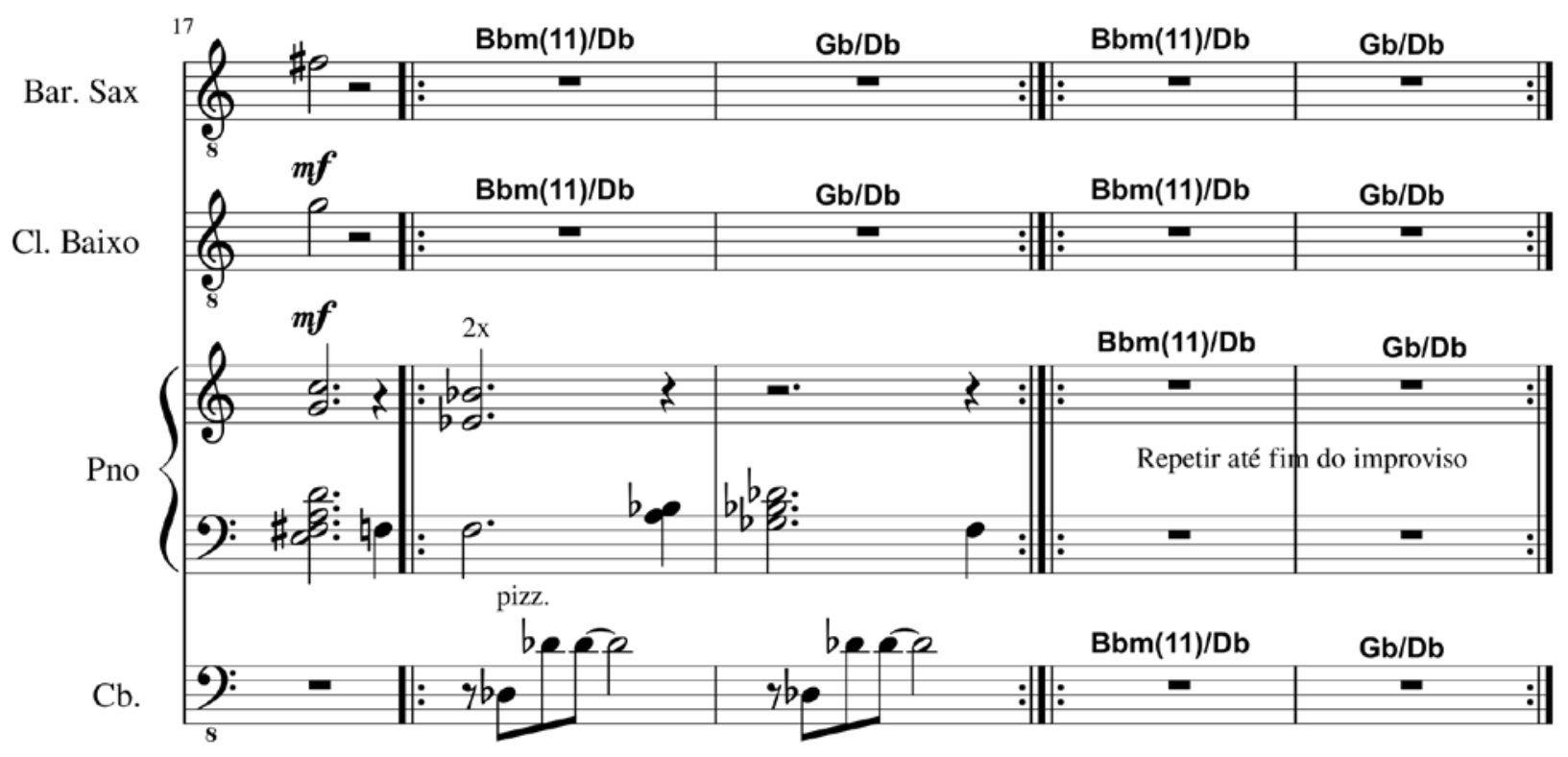

Fonte: Elaboração própria.

A demarcação da cifra acima dos compassos refere-se ao início da improvisação. Como citado, o acompanhamento é definido primeiramente; após, é livre para ser interpretado, respeitando-se a harmonia. O objetivo deste acompanhamento "livre" tem base na possibilidade de interação entre os intérpretes. Além disto, tanto o saxofone quanto o clarone improvisam juntos nesta parte, ocorrendo uma outra possibilidade de interatividade. A segunda abertura para improvisação ocorre após o retorno do tema na parte $B$. Há um novo enunciado com gestos que configuram a parte transitória; esta ponte inicia a tempo, porém, é demarcada posteriormente com rubato e, após, "descaracterizar as figuras". Portanto, tais elementos foram utilizados a fim de que esta descaracterização se tornasse um referente inicial para uma improvisação livre (sem elementos predeterminados), como é demarcado na partitura: 

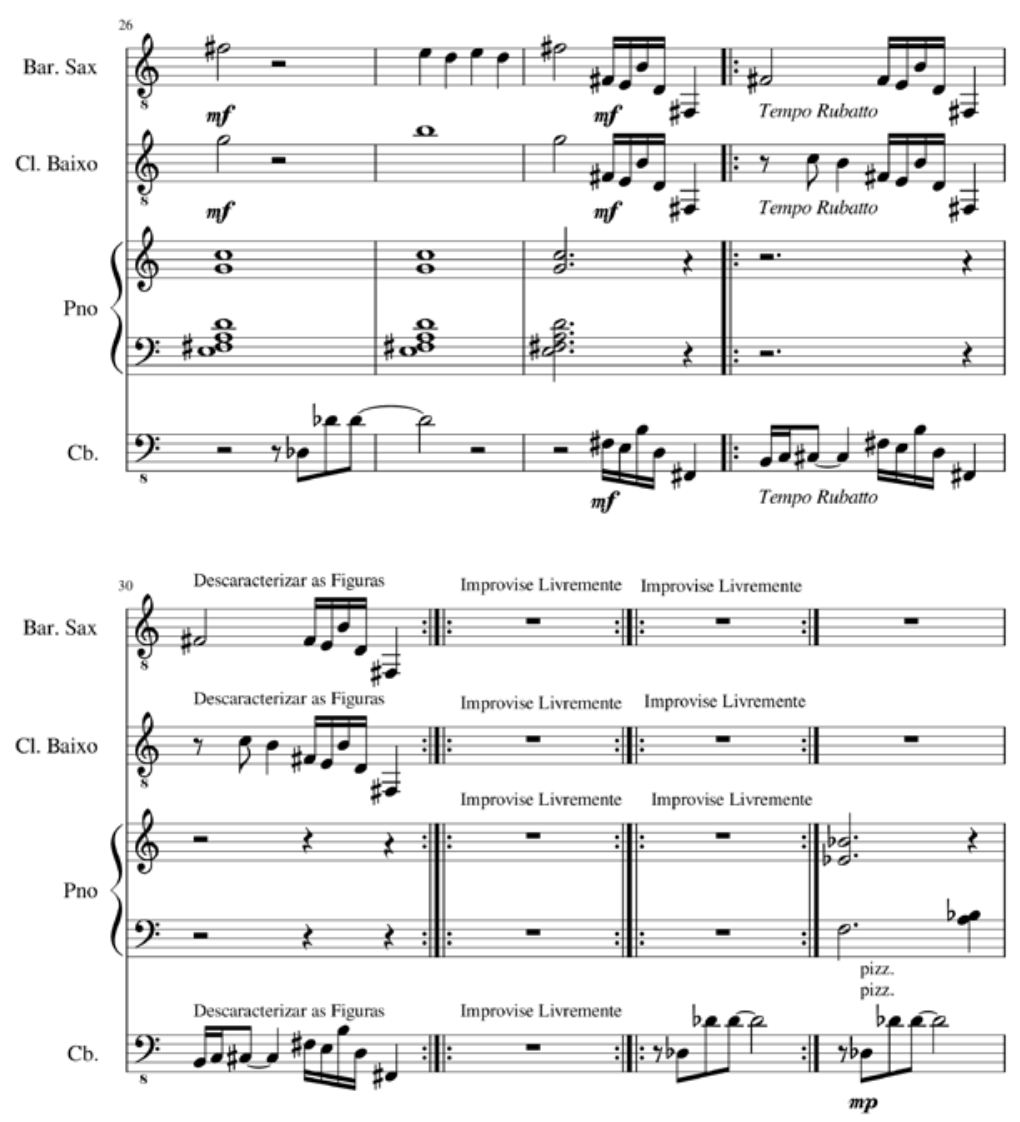

Fonte: Elaboração própria.

Nesta seção da peça, queremos compreender a influência dos temas anteriores na criação de referentes. Esta compreensão se dará a partir da análise comparativa entre as performances, como realizada em escafandro; se nesta houve influência da notação gráfica como referente, em sátira há a possibilidade da presença de um referente prévio gerado pela execução do tema e pela memória gestual da própria peça.

Após estas improvisações, há uma reexposição do tema; finaliza-se a peça em uma seção demarcada como uma improvisação. Cabe compreender os referentes que serão criados a fim de finalizar a peça. Como uma obra que possui um tema definido, foi analisado se os intérpretes realizarão uma improvisação a partir dos referentes gerados pela própria peça ou se finalizarão a partir de uma improvisação livre com referentes diversos em tempo real. 
Fig. 11 - Final de sátira com abertura à improvisação.

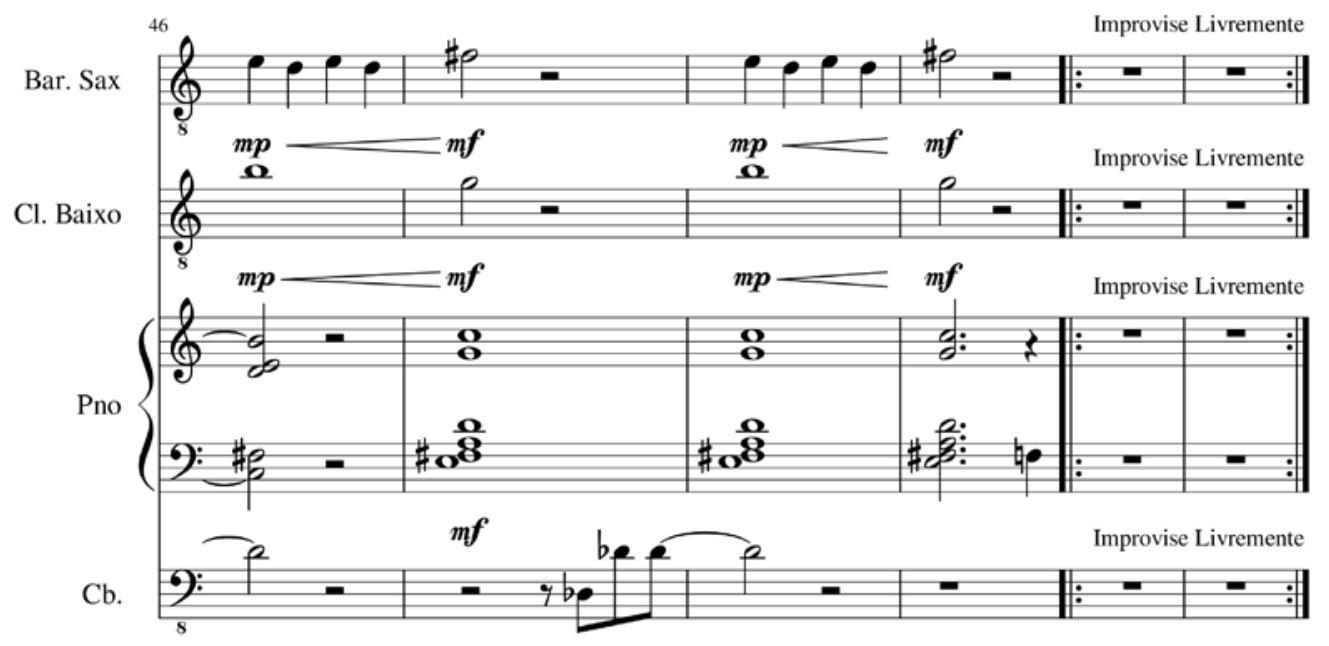

Fonte: Elaboração própria.

Há, nesta peça, uma construção temática: o material improvisado e selecionado na edição é transformado em material independente de contexto, por meio do uso da notação simbólica. Analisando-se três execuções da peça, ${ }^{14}$ a notação é respeitada e não há possibilidade de contingências. A primeira abertura à improvisação é demarcada, como mencionado, por meio da harmonia que o material improvisado inicial gera. O improvisador, em um primeiro contato com a peça, utiliza materiais que são parte de sua base de conhecimento com técnicas específicas (escalas, arpejos, possibilidades de frases melódicas que condizem com a harmonia exposta) e a experiência musical própria.

No evento em que ocorrem as desfragmentações das figuras, percebeu-se, nas três performances, influência desta ação no início das improvisações. É, portanto, um referente predefinido. Porém, em todas ele é descartado rapidamente, sendo que novos gestuais são produzidos e não remetem diretamente a elementos (tanto melódicos, rítmicos quanto texturais) da peça. Ou seja, novos referentes surgem ao longo da improvisação, e destituem-se de uma intencionalidade tendo em vista os elementos independentes de contexto. Já na improvisação que encerra a peça, perceberam-se aspectos semelhantes: os intérpretes revisitam gestuais da peça, criando-se referentes que já haviam sidos determinados, porém estes não são fixos. Portanto, as três performances possuem similaridades devido aos elementos independentes de contexto, porém em geral são descaracterizadas devido às improvisações existentes.

Acreditamos que sátira representa nossa visão sobre comprovisação. Ao pensarmos por meio da relação entre os fluxos interpretativos e improvisatórios, fica claro que estes são distintos na peça dado que existem demarcações claras de momentos composicionais e aberturas às improvisações. Porém, cabe mencionar a influência do aspecto composicional sobre as improvisações livres da peça. Em sua grande maioria, os intérpretes buscavam elementos já demarcados da peça para suas improvisações.

14 Realizadas em 29/10/2019, 12/11/2019 e 22/11/2019. 
Aspectos melódicos (o pedal do baixo, a melodia do tema), aspectos rítmicos (como por exemplo, a figura da parte transitória) são, em diversos momentos das performances realizadas, retomados ao longo das improvisações. Demonstram a permeabilidade e a influência existente ao executar uma comprovisação. Além disto, acreditamos que devido a esta influência, ocorra uma desestabilização do pacto - o ouvinte, ao se deparar com a peça, busca compreender quais seriam os elementos compostos ou improvisados, dado que os elementos de caráter improvisado são diretamente derivados dos elementos composicionais.

\section{4 locus}

A peça locus possui três movimentos e consiste em um tape, criado a partir de improvisações captadas e editadas do próprio grupo, que serve como um referente coletivo, ou seja, um elemento independente de contexto, com o qual os músicos interagem e improvisam. A peça não possui notação alguma. A hipótese a ser testada a partir da concepção desta peça recai sobre a intencionalidade composicional e como esta é influente na interpretação/improvisação, sendo elemento prévio. Partimos de uma pesquisa de Canonne (2018a), que realizou experimentos com um grupo de improvisação livre e um compositor, com o propósito de compreender a relação existente entre processos composicionais e improvisatórios em práticas musicais contemporâneas (informação verbal). Na palestra intitulada A Continuum of Improvisational Practices? Some More Thoughts on Improvisation, o autor descreve estes experimentos: com um grupo de improvisadores experientes, foi proposto um trabalho conjunto a um compositor. Este primeiramente escutava as improvisações e realizava notas sobre momentos da performance que considerava que poderiam ser diferentes, a fim de uma consolidação estética. Estas notas eram repassadas aos instrumentistas para que estes realizassem novas improvisações, ou seja, há um elemento composicional derivado do compositor que permeará a performance. Em outro momento, o compositor tomava notas sobre uma improvisação livre e criava uma partitura, a qual foi considerada indeterminada.

Estes experimentos foram considerados pelo pesquisador como um caminho para uma performance híbrida, na qual duas opções são possíveis para interpretação: a primeira consiste em "tocar a partitura altamente indeterminada do compositor, decidindo exatamente o que e como tocar ao longo da performance - assim, improvisando parte da performance"; a segunda opção seria "usar a partitura do compositor não como um template que a improvisação deve preencher, mas como um contexto para a improvisação".

Sobre a primeira opção, os músicos participantes compreendem a intencionalidade presente em duas maneiras: primeiramente, os apontamentos feitos pelo compositor, caso não sejam de acordo com a identidade do grupo como improvisadores, demonstram-se como exógenos e são percebidos como elementos de risco que não são incorporados pela lógica improvisatória do grupo. Outra maneira refere-se à incorporação deste material apontado pelo compositor à lógica improvisatória. Porém, o pesquisador reitera que "não é claro que eles sentirão que estão tocando a música de KN durante a 
improvisação" (sendo KN o compositor participante do experimento). Ou seja, a partir da integração do material, que em primeiro momento reflete uma operação composicional, este, em meio a uma lógica improvisatória, não é mais percebido como tal. $\mathrm{Na}$ segunda opção, Canonne percebe momentos autenticamente híbridos, nos quais os improvisadores abandonam a partitura do compositor e começam a improvisar - sendo que tais momentos apresentam claramente influência do material composicional.

Para as performances aqui analisadas, as instrumentações foram determinadas como seguinte: o primeiro movimento, no qual o tape consiste em uma edição com piano, contrabaixo e clarone, e a improvisação sob tal é de piano e clarone. O segundo movimento é um tape com instrumentação de piano e contrabaixo, sendo interpretado conjuntamente ao clarone. Por fim, um tape que consiste em saxofone barítono, clarone, contrabaixo e piano, sendo realizado por clarone, piano e contrabaixo. Nos ensaios, estas instrumentações foram variadas até serem definidas de tal maneira.

A característica marcante de tal peça é a intencionalidade composicional presente no tape e como esta influencia os instrumentistas ao realizarem improvisações sobre tal. Há uma integração do material do tape à lógica improvisatória do grupo. Nas performances realizadas da peça, perceberam-se as diferenciações dadas entre as interações possíveis - momentos nos quais os intérpretes interagiam entre si, por vezes criando uma lógica que remetesse a uma improvisação livre, sendo o tape "abandonado". Porém, nas mesmas performances percebe-se a influência que o tape possui na maneira de execução; acreditamos que locus possa ser considerada como o processo que Canonne denominou como híbrido. Ou seja, esta peça pode ser compreendida como uma comprovisação, a partir da concepção de interligação de fluxos interpretativos e improvisatórios.

Ressaltamos também que esta relação entre tape e improvisação sendo realizada em tempo real altera possibilidades perceptivas na recepção da obra. Sua execução contempla um elemento quase "externo" ao palco - a gravação - , e, na apresentação da peça percebeu-se que devido à instrumentação similar, os instrumentistas utilizavam o tape para buscar novas possibilidades sonoras. Estes elementos, dado que a peça não foi contextualizada previamente à sua execução, podem remeter em primeiro momento à hipótese de Lehmann e Kopiez (2010), no sentido de o ouvinte não distinguir elementos improvisatórios/composicionais mas direcionar sua percepção às fontes sonoras existentes. Sem sua contextualização prévia, poderíamos compará-las ao experimento de Canonne (2018b) - os ouvintes, devido à interação constante existente entre tape e improvisação, realizariam julgamentos de valor no que acreditassem que seria aquele processo criativo, improvisado ou composto. Cabe ressaltar que não realizamos um experimento empírico com coleta de dados, esta análise parte da visão do próprio autor. Caberia também, como complemento a esta pesquisa, buscar possibilidades de execução desta peça com outras instrumentações, além de entrevistas com os intérpretes e os ouvintes. Porém, uma vez que aqui buscamos discutir sobre o processo criativo, não nos atemos a estas metodologias ${ }^{15}$.

15 A fim de representação da interação resultante na peça locus, a peça em sua integralidade pode ser acessada em: https://www.youtube.com/ watch?v=b92pSjUdewQ\&ab_channel=M.Falleiros 


\section{Considerações Finais}

Acreditamos que esta pesquisa venha a contribuir com a compreensão de práticas musicais colaborativas por meio da noção de comprovisação. As peças aqui analisadas demonstram diferentes possibilidades criativas a partir da literatura que versa sobre este novo termo, ainda em desenvolvimento (tanto teórico quanto prático). Como mencionam Bhagwati (2013, p. 170) e Falleiros (2018), atualmente percebe-se que as definições sobre as práticas normalmente são baseadas em aspectos criativos individuais. Este debate é o cerne de nossa divisão em duas vertentes de noções sobre comprovisação: a primeira busca distinguir a prática de técnicas composicionais como o uso de aleatoriedade e indeterminação por meio de uma vinculação da comprovisação com a interação resultante da interpretação com tecnologias de edição e processamento de áudio. Já a segunda vertente busca compreender a comprovisação como parte desta complexidade de técnicas composicionais e improvisatórias, até mesmo englobando-as em sua possível definição.

Em nossa proposta, buscamos definir comprovisação como uma prática ou um processo criativo que se diferencia na multiplicidade existente na música contemporânea. Esta definição surge a partir da compreensão da prática em dois níveis: primeiramente, por meio da sua recepção por parte do ouvinte; em um segundo momento, por meio de características da performance. Em relação ao primeiro nível, relativo à percepção do ouvinte quando deparado com uma comprovisação, buscamos argumentar a partir da desestabilização do pacto, termo de Falleiros (2012). A partir das hipóteses de Lehmann e Kopiez (2010) e Canonne (2018b), percebemos que a percepção do ouvinte é normalmente direcionada à contextualização prévia da peça (seja esta dada previamente à execução da peça, ou derivada da base de conhecimento de possibilidades musicais em certos "estilos"). Estas possibilidades de contextualização refletiriam a noção do pacto, a fim de que o ouvinte compreenda e aceite a narrativa ficcional que está sendo direcionada a ele. No caso de uma comprovisação, dada a permeabilidade entre os processos composicionais e improvisatórios, ocorre como um "jogo" no qual a percepção do ouvinte se torna descontextualizada, mesmo havendo materiais que possam a direcionar para algum "estilo" musical ou a algum material que seja compreendido como composicional ou improvisatório. Desta forma, ocorre o que nomeamos como desestabilização deste pacto entre o ouvinte e a obra.

Já no campo da performance, a partir da visão de elementos generativos de Clarke (2001), buscamos argumentar sobre como há uma alteração clara entre os processos existentes para o intérprete quando este executa uma composição e quando executa uma improvisação. Dada a já mencionada permeabilidade dos processos composicionais e improvisatórios em uma comprovisação, o intérprete possuiria acesso a elementos de nível superior - aqueles que representam hierarquicamente elementos tradicionalmente composicionais -, assim como poderiam "gerar" elementos superiores a partir de referentes temporários - caracterizando elementos da improvisação. Esta transição entre elementos de nível superior, elementos gerados em concatenação e mesmo a inexistência em vezes destes elementos (resultando, por exemplo, em uma 
livre improvisação ao longo da peça) caracteriza o que chamamos de interligação dos fluxos de interpretação e improvisação, que representaria o processo de performance em uma comprovisação.

Para testarmos nossa compreensão sobre comprovisação, realizamos experimentos que culminaram em processos criativos. As quatro peças analisadas foram realizadas a fim de constatarmos possíveis interligações dos fluxos que mencionamos, além das relações perceptivas existentes quando há uma permeabilidade entre materiais composicionais e improvisatórios em uma mesma peça. A primeira, insígnia, baseada na compreensão de Michael Hannan (2006), Coleman (2016) e Rapson (MISTERY..., 2011), teve como fundamento a edição e transcrição de improvisações livres existentes. Como esta manipulação do material gera uma partitura tradicional sem aberturas a improvisações, sendo que os elementos possíveis de manipulação são poucos e não alteram a direcionalidade da peça, não percebemos uma interligação dos fluxos nem uma possível desestabilização do pacto dado que, ao apresentá-la, ela se mantém fixa e se caracteriza pelo surgimento de temas, além de sua possível reprodutibilidade. escafandro, a qual possui elementos como hard boxes e preza pela aleatoriedade, também não demonstra uma possibilidade de interligação dos fluxos nem da desestabilização do pacto, já que os intérpretes são limitados às possibilidades existentes na partitura.

Já na peça sátira, parece-nos ocorrer o que denominamos como a desestabilização do pacto além da interligação dos fluxos. O motivo de tal é a existência de possibilidades de livre improvisação ao longo da peça que, por possuir um material composicional delimitado, acaba retornando e influenciando as improvisações. Parece-nos que o material composicional se mantém como um possível referente para o início destas seções improvisadas, porém os caminhos tomados pelos intérpretes são múltiplos. Desta forma, abrem-se as possibilidades perceptivas, dado que por vezes os próprios temas existentes da peça retornam à improvisação. A última peça, locus, possui um processo diferenciado: improvisações sobre gravações realizadas previamente. O material composicional existente, portanto, consta nas gravações (e não como elementos na partitura, como nas outras peças). As improvisações realizadas tomam forma a partir destas gravações, demonstrando novamente como um referente externo (ou um material composicional prévio) influencia a direção da improvisação, mostrando-se as possibilidades de interligação de fluxos.

Por fim, acreditamos que esta pesquisa busca uma definição para o termo comprovisação, partindo de uma argumentação teórica, da observação e experimentação por meio de processos criativos. Acreditamos serem de valor as possibilidades aqui já demarcadas, especialmente dado o contexto da música contemporânea no qual inúmeras das práticas são normalmente descritas via aspectos individuais de cada compositor/improvisador. Além disso, a compreensão de comprovisação também nos parece válida ao nos situarmos no debate entre composição-improvisação, e compreendendo que tais processos não são opostos, mas, sim, complementares. 


\section{Referências}

ALIEL, Luzilei. Ensaios sobre comprovisações em ecologia sonora: perspectivas práticas e teóricas. São Paulo: Dissertação (Mestrado) - Escola de Comunicação e Artes, Universidade de São Paulo, São Paulo, 2017.

ALLEN, C. Paul Rutherford: A Musician's Impulse. All about jazz, 3 June 2006.

Disponível em: https://www.allaboutjazz.com/paul-rutherford-a-musicians-impulsepaul-rutherford-by-clifford-allen.php.

ANTAR, M. D.; OLIVEIRA, Y. D. Is that the show?! Comprovisation and occupation of public spaces at the TransPosições performance. In: SONOLOGIA 2016 - OUT OF PHASE - INTERNATIONAL CONFERENCE ON SOUND STUDIES, 2016, São Paulo. Proceedings [...]. São Paulo, 2017.

BAILEY, Derek. Improvisation: It's Nature and Practice in Music. Boston: Da Capo Press, 1993.

BHAGWATI, Sandeep. Notational Perspective and Comprovisation. In: ASSIS, K.; WILLIAM, C.; BROOKS, P. (ed.). Sound and Score: essays on sound, score and notation. Leuven: Leuven University Press, 2013.

BORGO, D. Sync or Swarm: Musical Improvisation and the Complex Dynamics of Group Creativity. In: HUTCHISON, D. (ed.). Algebra, Meaning, and Computation. Berlin, Heidel-berg: Springer Berlin Heidelberg, 2006. v. 4060, p. 1-24.

BOULEZ, Pierre. Alea. Perspectives of New Music, v. 3, n. 1, p. 42-53, 1964.

BRESSON, J.; CHADABE, J. Interactive composition: New steps in computer music research. Journal of New Music Research, v. 46, n. 1, 2017.

CANONNE, Clément. Du concept d'improvisation à la pratique de l'improvisation libre. International Review of the Aesthetics and Sociology of Music, v. 47, n. 1, p. 17-43, 2016.

CANONNE, Clément. Rehearsing Free Improvisation? An Etnography Study of Free Improvisers at Work. Music Theory Online, v. 24, n. 4, p. 1-36, $2018 \mathrm{a}$.

CANONNE, Clément. Listening to Improvisation. Empirical Musicology Review, v. 13, n. $1-2,2018 b$. 
CANONNE, Clement; AUCOUTURIER, Jean-Julien. Play Together, Think Alike: Shared mental models in expert music improvisers. Psychology of Music, v. 4, n. 33, p. 544558, 2015.

CANONNE, Clement; GARNIER, Nicolas. A Model for Collective Free Improvisation. In: MATHEMATICS AND COMPUTATION IN MUSIC: INTERNATIONAL CONFERENCE, 3. 2011, Paris. Proceedings [...]. Paris, 2011. p. 29-41.

CANONNE, Clement; GARNIER, Nicolas. Individual Decisions and Perceived Form in Collective Free Improvisation. Journal of New Music Research, v. 44, n. 2, p. 145-167, 2015a.

CANONNE, Clement; GARNIER, Nicolas. Cognition and Segmentation in Collective Free Improvisation: An Exploratory Study. In: INTERNATIONAL CONFERENCE ON MUSICAL PERCEPTION AND COGNITION, 2015. Proceedings [...]. [S. l.], 2015b.

CHADABE, Joel. Interacting Composing an Overview. Computer Music Journal, p. 2227, 1984.

CLARKE E. F. Generative principles in music performance. In: SLOBODA, J. (ed.). Generative Processes in Music: The Psychology of Performance, Improvisation and Composition. Oxford: Oxford University Press: Oxford Scholarship Online, 2001.

COLEMAN, T. Polycyclic Improvisation. Tese (Doutorado) - University of Otago, Dunedin, 2016.

COSTA, Rogério Luiz Moraes. Educação e pensamento musical: a improvisação e o desenvolvimento da percepção no processo de configuração do pensamento musical através de uma cognição criativa. In: ENCONTRO ANUAL DA ABEM, 10., 2001, Uberlândia. Anais [...]. Uberlândia, 2001.

COSTA, Rogério. Música errante: o jogo da improvisação livre. São Paulo: Fapesp; Perspectiva, 2016.

COSTA, R. L. M.; SCHAUB, S. Expanding the concepts of knowledge base and referent in the context of collective free improvisation. In: CONGRESSO DA ASSOCIAÇÃO NACIONAL DE PESQUISA E PÓS-GRADUAÇÃO EM MÚSICA, 18., 2013, Natal. Anais [...]. Natal, 2013. p. 8.

DAHLSTEDT, P.; NILSSON, P. A.; ROBAIR, G. The bucket system - a computer mediated signaling system for group improvisation. In: INTERNATIONAL CONFERENCE ON NEW INTERFACES FOR MUSICAL EXPRESSION, 2015, Los Angeles. Proceedings [...]. Los Angeles, 2015. 
DALE, M. What is Comprovisation? Tese (Doutorado) - Mills College, Oakland, 2008.

DELIĖGE, Celèstin. Indetermination et improvisation. International Review of the Aesthetics and Sociology of Music, v. 2, n. 2, p. 155-191, 1971.

DUDAS, Richard. "Comprovisation": The Various Facets of Composed Improvisation within Interactive Performance Systems. Leonardo Music Journal, v. 20, p. 29-31, Dec. 2010.

FALLEIROS, M. Palavras sem discurso: estratégias criativas na livre improvisação. Tese (Doutorado) - Universidade de São Paulo, São Paulo, 2012.

FARACO, Arthur. Reflexões sobre as noções de complexidade e emergência na livre improvisação coletiva. In: CONGRESSO DA ANPPOM, 30., 2020, Manaus. Anais [...]. Manaus: Universidade Federal do Amazonas, 2020.

FARACO, Arthur; FALLEIROS, Manuel. Análise da peça à deriva sob a perspectiva da comprovisação como prática experimental. In: ENCONTRO INTERNACIONAL DE TEORIA E ANÁLISE MUSICAL, 5., 2019, Campinas. Anais [...]. Campinas: Universidade Estadual de Campinas, 2019.

FUJAK, J. Comprovisación: notas para la discusión sobre la validez del concepto. Oro Molido, Madrid, v. 33, 2011.

FURLANETE, Fábio. Política da experiência estética: improvisação como objeto dos discursos artístico e acadêmico. In: CONGRESSO DA ANPPOM, 29., 2019, Pelotas. Anais [...]. Pelotas: Universidade Federal de Pelotas, 2019.

GLOBOKAR, V. Reacting. IIMA - International Improvised Music Archive, 1970.

Disponível em: http://intuitivemusic.dk/iima/vg_reacting.htm.

GOUDARD, V. John, the semi-conductor: a tool for comprovisation. In: INTERNATIONAL CONFERENCE ON TECHNOLOGIES FOR MUSIC NOTATION AND REPRESENTATION, 4., 2018. Proceedings [...]. [S. l.], 2018.

HAENISCH, M. Emergence: On a theoretical term in current improvisation research. In: BEINS, B.; KESTEN, C.; NAUCK, G.; NEUMANN, A. (ed.). Echtzemusik Berlin: Selfdefining a scene. Hofheim am Taunus: Wolke Verlag, 2011. p. 186-201.

HANNAN, Michael. Interrogating comprovisation as practice-led research. ePublications@SCU, Southern Cross University, p. 17, 2006. 
JOST, E. Free Jazz. 1. ed. Viena: Da Capo Press, 1994.

KUEHN, F. M. C. Interpretação - reprodução musical - teoria da performance: reunindo-se os elementos para uma reformulação conceitual das práticas interpretativas. Per Musi, Belo Horizonte, n. 26, p. 7-20, 2012.

LEEUW, T. d.; GROOT, R. d. Music of the twentieth century: a study of its elements and structure. Amsterdam: Amsterdam University Press, 2005.

LEHMANN, A. C.; KOPIEZ, R. The difficulty of discerning between composed and improvised music. Musicae Scientiae, ESCOM - European Society for the Cognitive Sciences of Music, p. 113-129, 2010.

LEWIS, George. Improvised music after 1950: Afrological and eurological perspectives. Black Music Research Journal, v. 16, n. 1 p. 91-122, 1996.

LOUZEIRO, P. The comprovisador's real time notation interface. In: INTERNATIONAL SYMPOSIUM ON CMMR, 13., 2017, Matosinhos (Portugal). Proceedings [...]. Matosinhos (Portugal), 2017.

MAILMAN, Joshua. Improvising synesthesia: Comprovisation of generative graphics and music. Leonardo Eletronic Almanac, v. 19, 2013

MISTERY and manners. Compositor: J. Rapson. Iowa City; Campinas: MOMU Records, 2011. 1 CD.

MOORE, R. The decline of improvisation in western art music: An interpretation of change. International Review of the Aesthetics and Sociology of Music, Zagreb, v. 23, n. 1, p. 61-84, 1992.

NASCIMENTO, J. P. C. do. Abordagens do pós-moderno em música: a incredulidade nas metanarrativas e o saber musical contemporâneo. São Paulo: Editora Unesp, 2011.

NETTL, Bruno. Thoughts on Improvisation: A Comparative Approach. The Musical Quarterly, v. 60, n. 1, p. 1-19, 1974.

NETTL, Bruno; RUSSEL, M. In the course of performance: studies in the world of musical improvisation. Chicago: University of Chicago Press, 1998.

NYMAN, Michael. Experimental music: Cage and beyond. 2. ed. Cambridge; New York: Cambridge University Press, 1999. 
OBIJIAKU, C. "Comprovisation" in igbo choral art music (icam): An introduction. Journal of The Musical Arts in Africa, v. 16, p. 127-142, 2019.

PAPAGEORGIOU, D. The notion of seyir as a conceptual and typological scheme for comprovisation. Principal of Music Composing: Phenomenom of Melody, v. 15, 2015.

PRESSING, Jeff. Psychological constraints on improvisation. In: NETTL, M. R. B. (ed.). In the Course of Performance: Studies inthe World of Musical Improvisation. Chicago: The University of Chicago Press, 1998.

SAVOURET, Alain. Introduction à un solfège de l'audible: l'improvisation libre comme outil pratique. Lyon: Symétrie, 2010.

SAWYER, Keith. Group Creativity: Music, theater, collaboration. New York: Routledge, 2003.

SMALL, Christopher. Musicking: the meanings of performance and listening. Music / Culture, Wesleyan University Press, 1998.

STENSTRÖM, H. Free ensemble improvisation. Tese (Doutorado) - Academy of Music and Drama, Faculty of Fine, Applied and Performing Arts, University of Gothenburg, Göteborg, 2009.

STEWART. J. No Boundary Line to Art: "Bebop" as Afro-Modernist Discourse. American Music, v. 29, n. 3, p. 332, 2011.

STONE, K. Music Notation in the Twentieth Century. New York; London: W. W. Norton \& Company, 1980.

TRENKAMP, A. The Concept of 'Alea' in Boulez's 'Constellation-Miroir'. Music \& Letters, v. 57, n. 1, p. 1-10, 1976.

VASSILANDONAKIS, Y. An Interview with Trevor Wishart. Computer Music Journal, v. 33, n. 2, p. 8-23, June 2009. 